\title{
Size distribution and optical properties of mineral dust aerosols transported in the western Mediterranean
}

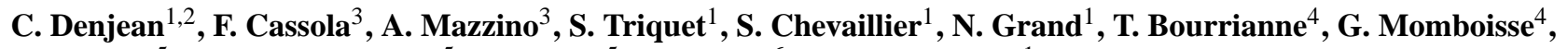 \\ K. Sellegri ${ }^{5}$, A. Schwarzenbock ${ }^{5}$, E. Freney ${ }^{5}$, M. Mallet ${ }^{6}$, and P. Formenti ${ }^{1}$ \\ ${ }^{1}$ Laboratoire Interuniversitaire des Systèmes Atmosphériques (LISA), UMR-CNRS 7583, Université Paris-Est-Créteil \\ (UPEC) et Université Paris Diderot (UPD), Institut Pierre Simon Laplace (IPSL), Créteil, France \\ ${ }^{2}$ Leibniz Institute for Tropospheric Research (TROPOS), Permoserstraße 15, Leipzig, Germany \\ ${ }^{3}$ Department of Physics and INFN, Genoa, Italy \\ ${ }^{4}$ Centre National de Recherches Météorologiques (CNRM), Météo-France, Toulouse, France \\ ${ }^{5}$ Laboratoire de Météorologie Physique (LaMP), CNRS/Université Blaise Pascal, Clermont-Ferrand, France \\ ${ }^{6}$ Laboratoire d'Aérologie (LA), Université de Toulouse, CNRS, Toulouse, France
}

Correspondence to: C. Denjean (cyrielle.denjean@meteo.fr) and P. Formenti (paola.formenti@lisa.u-pec.fr)

Received: 9 July 2015 - Published in Atmos. Chem. Phys. Discuss.: 10 August 2015

Revised: 12 December 2015 - Accepted: 1 January 2016 - Published: 1 February 2016

\begin{abstract}
This study presents in situ aircraft measurements of Saharan mineral dust transported over the western Mediterranean basin in June-July 2013 during the ChArMEx/ADRIMED (the Chemistry-Aerosol Mediterranean Experiment/Aerosol Direct Radiative Impact on the regional climate in the MEDiterranean region) airborne campaign. Dust events differing in terms of source region (Algeria, Tunisia and Morocco), time of transport (1-5 days) and height of transport were sampled. Mineral dust were transported above the marine boundary layer, which conversely was dominated by pollution and marine aerosols. The dust vertical structure was extremely variable and characterized by either a single layer or a more complex and stratified structure with layers originating from different source regions. Mixing of mineral dust with pollution particles was observed depending on the height of transport of the dust layers. Dust layers carried a higher concentration of pollution particles below $3 \mathrm{~km}$ above sea level (a.s.l.) than above $3 \mathrm{~km}$ a.s.l., resulting in a scattering Ångström exponent up to 2.2 below $3 \mathrm{~km}$ a.s.l. However, the optical properties of the dust plumes remained practically unchanged with respect to values previously measured over source regions, regardless of the altitude. Moderate absorption of light by the dust plumes was observed with values of aerosol single scattering albedo at $530 \mathrm{~nm}$ ranging from 0.90 to 1.00 . Concurrent calculations from the aerosol chemical composition revealed
\end{abstract}

a negligible contribution of pollution particles to the absorption properties of the dust plumes that was due to a low contribution of refractory black carbon in regards to the fraction of dust and sulfate particles. This suggests that, even in the presence of moderate pollution, likely a persistent feature in the Mediterranean, the optical properties of the dust plumes could be assumed similar to those of native dust in radiative transfer simulations, modelling studies and satellite retrievals over the Mediterranean. Measurements also showed that the coarse mode of mineral dust was conserved even after 5 days of transport in the Mediterranean, which contrasts with the gravitational depletion of large particles observed during the transport of dust plumes over the Atlantic. Simulations with the WRF mesoscale meteorological model highlighted a strong vertical turbulence within the dust layers that could prevent deposition of large particles during their atmospheric transport. This has important implications for the dust radiative effects due to surface dimming, atmospheric heating and cloud formation. The results presented here add to the observational data set necessary for evaluating the role of mineral dust on the regional climate and rainfall patterns in the western Mediterranean basin and understanding their atmospheric transport at global scale. 


\section{Introduction}

Mineral dust aerosols constitute a major fraction of airborne particulate matter (Huneeus et al., 2012) and their contribution to the Earth's climate system is of considerable significance. In particular, dust aerosols exert a significant effect on global radiative budget by scattering and absorbing longwave and shortwave radiation (IPCC, 2013), thereby impacting the vertical profile of temperature and atmospheric stability (Jing et al., 2008) and the precipitation rate (Rosenfeld et al., 2001; Andreae and Rosenfeld, 2008; Choobari et al., 2014).

The Sahara hosts the maximum dust emission and atmospheric dust loading in the world (Choobari et al., 2014). Strong winds and convection produced by intense surface heating can uplift mineral dust particles into the free troposphere, where they are advected over large distances at the continental and intercontinental scales (d'Almeida, 1986; Goudie and Middleton, 2001; Engelstaedter et al., 2006). Along the year, the transport pathway of Saharan dust is mainly controlled by low-pressure systems over the Atlantic or North Africa, high pressure over the Mediterranean region or high pressure at upper levels over Africa (Moulin et al., 1998; Querol et al., 2009; Salvador et al., 2014). A significant fraction of dust loaded from African sources is transported westward across the Atlantic Ocean as far as the Caribbean (Maring et al., 2003; Doherty et al., 2008), the United States (Perry et al., 1997; Prospero et al., 2002) and South America (Swap et al., 1992; Formenti et al., 2001; Ansmann et al., 2009). Large Saharan dust storms are also carried across the Mediterranean Sea to Europe (Moulin et al., 1998; Koren et al., 2003; Collaud Coen et al., 2004; Van Dingenen et al., 2005; Papayannis et al., 2008). During such outbreaks, mineral dust emerges as the largest $\mathrm{PM}_{10}$ source at rural and urban sites in the Mediterranean basin (Pey et al., 2013; Salvador et al., 2014).

Considerable uncertainties in quantifying the climatic effect of mineral dust arise from a lack of knowledge of their properties and spatial and vertical distributions over many regions of the world. In particular, to estimate the magnitude of the dust radiative effect, an accurate description of particle size distribution, optical properties and their link with the chemical composition is necessary (Sokolik and Toon, 1996; Tegen et al., 1996). The size distribution is a fundamental parameter to estimate the aerosol radiative effect and atmospheric lifetime, but its representation remains challenging due to the large size spectrum of mineral dust, from hundreds of nanometres to tens of micrometres (Formenti et al., 2011a). In particular, an accurate description of the coarse mode particles is vital since the presence of large particles enhances the capacity of mineral dust in absorbing radiation at short and long wavelengths (McConnell et al., 2008; Otto et al., 2009; Sicard et al., 2014), modifies the atmospheric heating rate (Ryder et al., 2013a) and affects cloud formation (Koehler et al., 2009).
Once in the atmosphere, mineral dust can undergo various aging processes, such as heterogeneous reactions with gas-phase compounds (Sullivan and Weber, 2006; Ma et al., 2012), condensation of low-volatile species (Bauer et al., 2004; Clarke et al., 2004; Sullivan and Prather, 2007), cloud processing (Levin et al., 1996; Trochkine et al., 2003) and coagulation (Fan et al., 1996; Zhou et al., 1996; Levin et al., 2005). Because of these processes, the physicochemical properties (composition, mixing state, shape and size distribution) of dust aerosols might evolve during transport, leading in turn to the evolution of the optical properties (Formenti et al., 2011a). A recent study of Kanitz et al. (2014) has shown significant differences in the optical properties of two Saharan dust plumes over the Atlantic Ocean, resulting from different aging processes affecting the dust. Henceforth, the radiative effect of mineral dust should depend on the travel distance and pathway, residence time over their source regions and air masses encountered (Garrett et al., 2003).

The Mediterranean basin provides ideal conditions to investigate the changes in Saharan dust properties as numerous concurrent anthropogenic and natural sources of aerosols are active over this region. Case studies of mixing of Saharan dust with industrial/urban, marine and biomass-burning particles have been documented in the past (Koçak et al., 2012; Mantas et al., 2014) and could explain the large variability of the values of single scattering albedo $\omega_{0}(0.83-0.92$ at the wavelength of $440 \mathrm{~nm}$ ) reported by various studies (Sicard et al., 2012; Mallet et al., 2013).

In past years, intensive field campaigns including in situ airborne measurements have mostly focused on properties of mineral dust at emission (e.g. over the Saharan and the Sahelian source regions) and over the Atlantic Ocean and on their comparison to trace the temporal evolution during transport (Formenti et al., 2003, 2011b; Reid et al., 2003; McConnell et al., 2008; Osborne et al., 2008; Heintzenberg, 2009; Weinzierl et al., 2009, 2011; Haywood et al., 2011; Ryder et al., 2013a, b). Contrastingly, observations in the Mediterranean region were mostly limited to remote sensing from the ground (e.g. Hamonou et al., 1999; Meloni et al., 2006; Saha et al., 2008; Basart et al., 2009; Gómez-Amo et al., 2011; Perrone and Bergamo, 2011; Mallet et al., 2013; Pey et al., 2013; Marconi et al., 2014) or space (Moulin et al., 1997; de Meij and Lelieveld, 2011; Gkikas et al., 2012).

To fill this gap, the Aerosol Direct Radiative Impact on the regional climate in the MEDiterranean region (ADRIMED) field campaign, part of the international cooperative research program ChArMEx (the Chemistry-Aerosol Mediterranean Experiment; http://charmex.lsce.ipsl.fr), took place with the main objectives of characterizing Saharan dust plumes by coordinated aircraft and ground-based measurements (Mallet et al., 2015). In this paper, we present in situ aircraft measurements obtained in June-July 2013 over the Mediterranean basin. The objective is to determine possible changes of dust properties during long-range transport over the west- 
ern Mediterranean basin and explore the potential reasons for changes.

Section 2 describes the aircraft strategy, the instrumentation and the method used to determine the aerosol size distribution, chemical composition and the associated optical properties. Section 3 presents the campaign meteorology, the dust vertical profiles and the results of the aerosol properties within the dust plumes. Section 4 explores the potential factors affecting the variability of the aerosol properties due to altitude and dust age. Section 5 concludes this article.

\section{Measurement and methodology}

\subsection{Aircraft strategy}

The ATR-42 aircraft of SAFIRE (French aircraft service for environmental research, http://www.safire.fr) based at Cagliari $\left(39^{\circ} 15^{\prime} \mathrm{N}, 9^{\circ} 03^{\prime} \mathrm{E}\right.$; Italy) conducted 16 flights in the period 14 June-4 July 2013. In this paper, we present results from the nine flights dedicated to the observation of mineral dust plumes that occurred between 16 June and 3 July 2013. These flights were carefully selected to provide measurements of air masses from dust active sources based on the analysis of satellite images and backward trajectories, as described in Sect. 2.4.

The ATR-42 aircraft performed research flights in the area between $35-43^{\circ} \mathrm{N}$ and $-4-13^{\circ} \mathrm{E}$, covering the western Mediterranean region, to probe the Saharan dust properties in a range of varying transport pathways and source regions. The flight tracks are shown in Fig. 1 and a summary of flight information is provided in Table 1 .

The airborne missions were planned using four different dust plume forecast models (MACC ALADIN-Dust, SKIRON and BSC-DREAM8b v2.0) and satellite images from the Spinning Enhanced Visible and Infrared Imager (SEVIRI) radiometer on the Meteosat Second Generation (MSG) satellite, all available in real time from the ChArMEx Operating Center (http://choc.sedoo.fr/) during the campaign. A general weather forecast was made daily by the French school of meteorology (ENM), at Météo-France in Toulouse.

The general flight strategy consisted of two main parts. First, profiles from $300 \mathrm{~m}$ up to $6 \mathrm{~km}$ above sea level (a.s.l.) were conducted by performing a spiral trajectory $10-20 \mathrm{~km}$ wide to sound the vertical structure of the atmosphere and identify interesting dust layers. Afterwards, the identified dust layers were probed by straight levelled runs (SLRs), where the aircraft flew at fixed altitudes, to provide information on dust spatial variability and properties. Horizontal flight legs in the dust layers lasted 20-40 min to allow aerosol collection on filters for chemical analyses in the laboratory. At the typical aircraft cruise speed of $100 \mathrm{~m} \mathrm{~s}^{-1}$, samples had spatial resolution ranging from 121 to $242 \mathrm{~km}$.

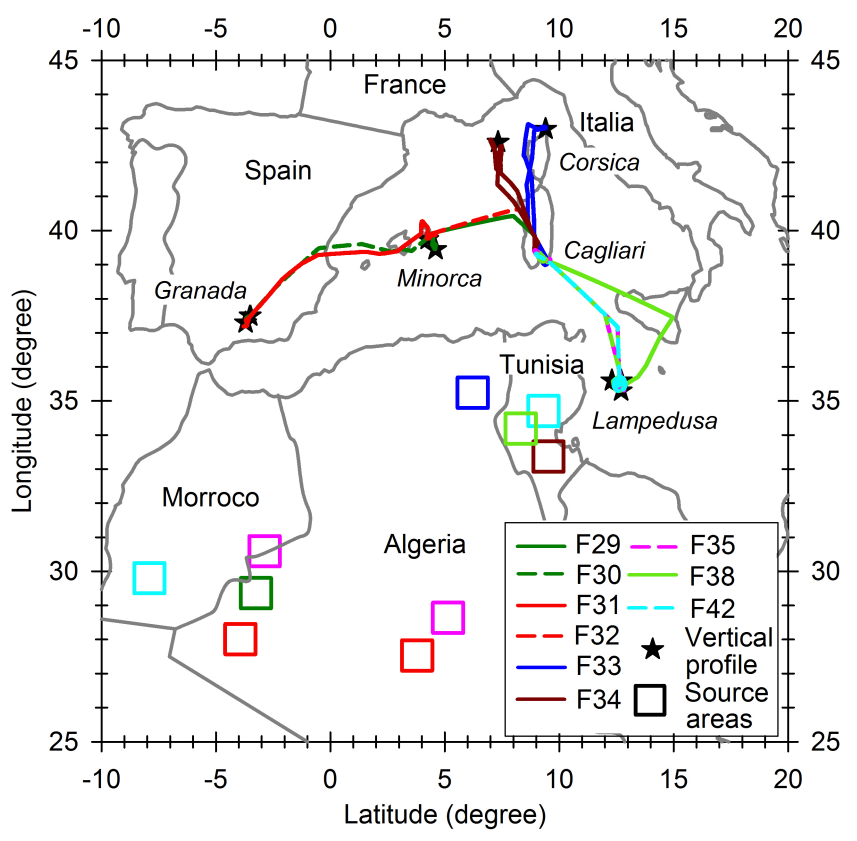

Figure 1. Operating region of the ATR-42 aircraft during the ADRIMED flights that performed mineral dust measurements. Colours of the lines and squares correspond to the different flights. The positions of the middle of the profiles are shown in black stars. Squares indicate likely sources regions of the dust sampled during the flights (see Sect. 3.1 for identification methodology). The aircraft was based at Cagliari in Sardinia.

\subsection{Instrumentation}

The ATR-42 basic instrumentation provides meteorological parameters including temperature, dew point temperature, pressure, turbulence, relative humidity, wind speed, direction, $\mathrm{CO}$ and $\mathrm{O}_{3}$ concentrations (Saïd et al., 2010). Only instruments relevant to microphysical properties, chemical composition and optical properties of aerosols are detailed in Table 2.

\subsubsection{Aerosol concentration and size distribution}

The total number concentration of particles larger than $5 \mathrm{~nm}$ in diameter was measured using a butanol-based condensation nucleus counter (CPC, TSI model 3075) corrected for coincidences.

The particle number size distribution was measured over the largest possible size spectrum by combining optical and electrical mobility techniques. The number size distribution in the submicron range was measured with an in-cabin scanning mobility particle sizer (SMPS) and a wing-mounted ultra-high sensitivity aerosol spectrometer (UHSAS, Droplet Measurement Technologies). The SMPS consisted of a differential mobility analyzer (DMA, Villani et al., 2007) interfaced to a condensation particle counter (CPC, TSI model 3010). A closed-loop recirculation was used for the sheath 
Table 1. Detailed information about the flights (number (ID), date, take-off time (TO), landing time (L) and route), the vertical profiles (latitude (lat), longitude (long) and start time) and the dust layers sampled (height in metres, origin, age in day) during the ChArMEx/ADRIMED airborne campaign. Times are expressed in coordinated universal time (UTC).

\begin{tabular}{|c|c|c|c|c|c|c|c|c|c|c|}
\hline \multicolumn{5}{|c|}{ Flight information } & \multicolumn{3}{|c|}{ Vertical profile } & \multicolumn{3}{|c|}{ Dust layer } \\
\hline ID & Date & TO & $\mathrm{L}$ & Flight route & Lat & Long & Start time & Height & Origin & Age \\
\hline F29 & 16 June 2013 & 08:18 & $10: 20$ & Cagliari-Minorca & $40^{\circ} \mathrm{N}$ & $5^{\circ} \mathrm{E}$ & 09:50 & $2200-4500$ & southwestern Algeria & 4.5 \\
\hline F30 & 16 June 2013 & $11: 58$ & $14: 40$ & Minorca-Granada & $37^{\circ} \mathrm{N}$ & $4^{\circ} \mathrm{W}$ & $14: 20$ & $2400-4800$ & southwestern Algeria & 4 \\
\hline F31 & 17 June 2013 & 07:15 & 09:54 & Granada-Minorca & $37^{\circ} \mathrm{N}$ & $4^{\circ} \mathrm{W}$ & $07: 15$ & $2800-5400$ & southern Algeria & 3.5 \\
\hline F32 & 17 June 2013 & $11: 45$ & $13: 43$ & Minorca-Cagliari & $40^{\circ} \mathrm{N}$ & $5^{\circ} \mathrm{E}$ & $11: 45$ & $1000-4600$ & southwestern Algeria & 4.5 \\
\hline F33 & 19 June 2013 & $11: 35$ & 15:00 & Cagliari-eastern Corsica & $43^{\circ} \mathrm{N}$ & $9^{\circ} \mathrm{E}$ & $12: 50$ & $\begin{array}{l}3000-4000 \\
1500-3000\end{array}$ & $\begin{array}{l}\text { northeastern Algeria } \\
\text { northeastern Algeria }\end{array}$ & $\begin{array}{l}2 \\
3\end{array}$ \\
\hline F34 & 20 June 2013 & 11:00 & 14:15 & Cagliari-western Corsica & $43^{\circ} \mathrm{N}$ & $7^{\circ} \mathrm{E}$ & $12: 20$ & $\begin{array}{l}>2800 \\
1600-2800\end{array}$ & $\begin{array}{l}\text { Tunisia } \\
\text { Tunisia }\end{array}$ & $\begin{array}{l}1 \\
5\end{array}$ \\
\hline F35 & 22 June 2013 & 08:47 & $11: 26$ & Cagliari-Lampedusa & $36^{\circ} \mathrm{N}$ & $13^{\circ} \mathrm{E}$ & $10: 25$ & $\begin{array}{l}>3500 \\
1500-3500\end{array}$ & $\begin{array}{l}\text { southern Algeria } \\
\text { southern Morocco }\end{array}$ & $\begin{array}{l}2 \\
4\end{array}$ \\
\hline F38 & 28 June 2013 & 10:59 & $13: 29$ & Cagliari-Lampedusa & $36^{\circ} \mathrm{N}$ & $13^{\circ} \mathrm{E}$ & $12: 30$ & $1200-4500$ & Tunisia & 3 \\
\hline F42 & 3 July 2013 & 08:29 & $11: 55$ & Cagliari-Lampedusa & $36^{\circ} \mathrm{N}$ & $13^{\circ} \mathrm{E}$ & 09:50 & $\begin{array}{l}>3000 \\
<3000\end{array}$ & $\begin{array}{l}\text { Tunisia } \\
\text { southern Morocco }\end{array}$ & $\begin{array}{l}3.5 \\
3.5\end{array}$ \\
\hline
\end{tabular}

Table 2. Instruments detailed in this article operating on board the ATR-42 aircraft during the ChArMEx/ADRIMED campaign. The cut-off diameter value, expressed as optical equivalent, is $12 \mu \mathrm{m}$ for the AVIRAD inlet and $5 \mu \mathrm{m}$ for the community aerosol inlet.

\begin{tabular}{|c|c|c|c|c|c|c|}
\hline $\begin{array}{l}\text { Parameter } \\
\text { measured }\end{array}$ & Instrument & Abbreviation & $\begin{array}{l}\text { Location in } \\
\text { the aircraft }\end{array}$ & $\begin{array}{l}\text { Wavelength } \\
(\mathrm{nm})\end{array}$ & $\begin{array}{l}\text { Nominal size } \\
\text { range }(\mu \mathrm{m})\end{array}$ & $\begin{array}{l}\text { Temporal } \\
\text { resolution }\end{array}$ \\
\hline \multirow[t]{4}{*}{ Size distribution } & $\begin{array}{l}\text { Forward scattering spectrometer probe, } \\
\text { Model } 300 \text {, Particle Measuring Systems }\end{array}$ & FSSP-300 & wing-mounted & 632.8 & $0.28-20$ & $1 \mathrm{~s}$ \\
\hline & $\begin{array}{l}\text { Ultra-high sensitivity aerosol spectrom- } \\
\text { eter, Droplet Measurement Technolo- } \\
\text { gies }\end{array}$ & UHSAS & wing-mounted & 1054 & $0.04-1$ & $1 \mathrm{~s}$ \\
\hline & $\begin{array}{l}\text { Sky-optical particle counter, model } \\
1.129 \text {, Grimm Technik }\end{array}$ & GRIMM & AVIRAD inlet & 655 & $0.25-32$ & $6 \mathrm{~s}$ \\
\hline & $\begin{array}{l}\text { Scanning mobility particle sizer, } \\
\text { custom-built (Villani et al., 2007) }\end{array}$ & SMPS & community aerosol inlet & $\mathrm{n} / \mathrm{a}$ & $0.03-0.4$ & $2 \mathrm{~min}$ \\
\hline Integrated number concentration & $\begin{array}{l}\text { Condensation particle counters, model } \\
3075 \text {, TSI }\end{array}$ & $\mathrm{CPC}$ & AVIRAD inlet & $\mathrm{n} / \mathrm{a}$ & $>0.005$ & $1 \mathrm{~s}$ \\
\hline Chemical composition & $\begin{array}{l}\text { Filter sampling } \\
\text { Single particle soot photometer, Droplet } \\
\text { Measurement Technologies }\end{array}$ & $\begin{array}{l}\mathrm{n} / \mathrm{a} \\
\mathrm{SP} 2\end{array}$ & $\begin{array}{l}\text { AVIRAD inlet } \\
\text { community aerosol inlet }\end{array}$ & $\begin{array}{l}\mathrm{n} / \mathrm{a} \\
1064\end{array}$ & $\begin{array}{l}\mathrm{n} / \mathrm{a} \\
0.08-0.5\end{array}$ & $\begin{array}{l}20-40 \mathrm{~min} \\
1 \mathrm{~s}\end{array}$ \\
\hline Scattering coefficient & $\begin{array}{l}3 \lambda \text { integrated nephelometer, model } \\
3563 \text {, TSI }\end{array}$ & Nephelometer & AVIRAD inlet & $450,550,700$ & $\mathrm{n} / \mathrm{a}$ & $1 \mathrm{~s}$ \\
\hline Extinction coefficient & $\begin{array}{l}\text { Cavity attenuated phase shift, Aerodyne } \\
\text { Research Inc. }\end{array}$ & CAPS & community aerosol inlet & 530 & $\mathrm{n} / \mathrm{a}$ & $1 \mathrm{~s}$ \\
\hline
\end{tabular}

n/a: not applicable

flow of the DMA. The SMPS system provided the number size distribution of the electrical mobility diameter from the $30-400 \mathrm{~nm}$ in 135 nominal size classes (i.e. size classes provided by the instrument not corrected for the dynamic shape factor) over time scans lasting $120 \mathrm{~s}$. Therefore, only data acquired during SLRs are considered. Data were processed by taking into account the particle electrical charging probabilities, the CPC counting efficiencies, the DMA transfer functions and the diffusion losses in the SMPS and CPC systems. The UHSAS is an optical-scattering laser-based aerosol spectrometer, providing the number size distribution of the optical equivalent diameter from 0.04 to $1 \mu \mathrm{m}$ in 99 nominal size classes at a time resolution of $1 \mathrm{~s}$. The spectrometer integrates light scattering between 22 and $158^{\circ}$ at
$1054 \mathrm{~nm}$. Due to reduced counting efficiency at size larger than $0.9 \mu \mathrm{m}$, only data at lower sizes are considered in this paper. The uncertainties on the particle diameter were estimated to be 5 and $10 \%$ for the SMPS and UHSAS respectively (Wiedensohler et al., 2012; Cai et al., 2008).

The number size distribution in the supermicron range was measured by the combination of two different optical particle counters (OPCs). A wing-mounted forward scattering spectrometer probe (FSSP, Particle Measuring System, model 300) measured the optical size distribution in the nominal size range of 0.28 to $20 \mu \mathrm{m}$ (Baumgardner et al., 1992). Data were recorded in 30 size classes at $1 \mathrm{~s}$ intervals. The FSSP-300 is based on the measurement of the light scattered between 3 and $12^{\circ}$ at $632.8 \mathrm{~nm}$. The FSSP has an uncer- 
tainty in diameter of about $30 \%$ according to Baumgardner et al. (1992). A GRIMM OPC (model sky-OPC 1.129) operated inside the cabin at a $6 \mathrm{~s}$ time resolution for measuring the optical size distributions between 0.3 and $32 \mu \mathrm{m}$ on 32 size classes in nominal diameter. However, only data at nominal size below $12 \mu \mathrm{m}$ were considered here due to the passing efficiency of the aerosols inlets connected to the GRIMM (see Sect. 2.3.2. for further information). The instrument integrates light scattering between 30 and $150^{\circ}$ at $655 \mathrm{~nm}$. According to the calibration of the GRIMM with size-standard particles, we assumed an uncertainty in diameter of $10 \%$.

\subsubsection{Aerosol chemical composition}

Bulk aerosol samples were collected on board by filtration through two stainless-steel filter units mounted in parallel. Sampling was performed only during constant altitude sequences lasting more than $25 \mathrm{~min}$ in order to guarantee sufficient mass loading of the filter samples. After exposure, samples were stored and transported at $-20^{\circ} \mathrm{C}$ to avoid later modification. Once in the laboratory, samples collected on $42 \mathrm{~mm}$ diameter polycarbonate membranes (nominal pore size $0.4 \mu \mathrm{m}$ Nuclepore, Whatman) were cut in halves that were analysed to yield both the elemental and ionic composition. Concentrations of elements from $\mathrm{Na}$ to $\mathrm{Pb}$ were measured by wavelength-dispersive X-ray fluorescence using a PW-2404 spectrometer (Panalytical). Details of the analytical protocols are provided by Formenti et al. (2008). The concentration of water-soluble ions were determined by ion chromatography (IC) with a Metrohm IC 850 device equipped with an injection loop of $100 \mu \mathrm{L}$. For anionic species, IC has been equipped with Metrosep A Supp 16 $(250 / 4.0 \mathrm{~mm})$ column associated with a Metrosep A Supp 16 guard pre-column heated at $65^{\circ} \mathrm{C}$. For simultaneous separation of inorganic and short-chain organic anions, elution has been realized with eluant composed at $20 \%$ by ultrapure water and at $80 \%$ by a solution $7.5 \mathrm{mM} \mathrm{Na}_{2} \mathrm{CO}_{3}$ and $0.75 \mathrm{mM} \mathrm{NaOH}$. The elution flow rate was $0.8 \mathrm{~mL} \mathrm{~min}^{-1}$. For cationic species, IC has been equipped with a Metrosep C4 (250/4.0 mm) column associated with a Metrosep C4 guard column heated at $30^{\circ} \mathrm{C}$. Elution has been realized with an eluant composed with $0.7 \mathrm{mM}$ of dipicolinic acid and $1.7 \mathrm{mM}$ of nitric acid. The elution flow rate was $1 \mathrm{~mL} \mathrm{~min}^{-1}$.

The mass concentration of refractory black carbon particles (rBC) was measured using a single particle soot photometer (SP2, DMT). The SP2 uses a continuous intra-cavity $\mathrm{Nd}$ :YAG laser at the wavelength of $1064 \mathrm{~nm}$ to heat $\mathrm{rBC}$ containing particles to their vaporization point. Single particle $\mathrm{rBC}$ mass was derived from the peak intensity of the thermal radiation emitted by the incandescent $\mathrm{rBC}$ detected by the SP2. This method allows the quantification with $100 \%$ efficiency of $\mathrm{rBC}$ mass in single particles with mass equivalent diameters between 80 and $500 \mathrm{~nm}$ (Moteki and Kondo, 2010). The total rBC mass loading was reported as the sum of all the detected single particle rBC masses. Prior to the

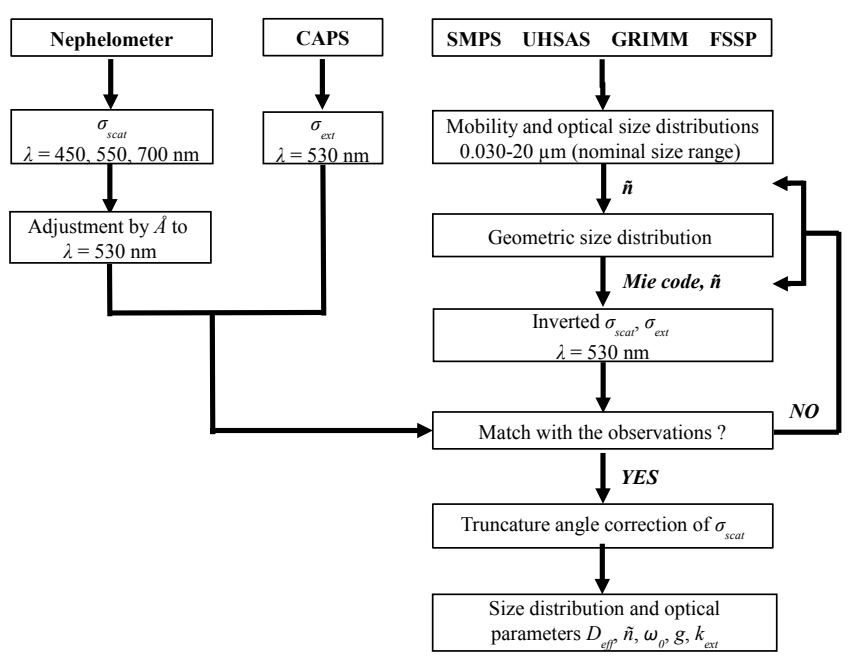

Figure 2. Data inversion procedure to retrieve the dust size distribution and optical parameters.

measurement field campaign, the SP2 was calibrated using fullerene soot particles, which have been shown to give similar SP2 response as ambient rBC (Moteki and Kondo, 2010; Baumgardner et al., 2012; Laborde et al., 2012).

\subsubsection{Aerosol scattering and extinction coefficients}

The particle scattering coefficient $\left(\sigma_{\text {scat }}\right)$ was measured at three wavelengths $(450,550$ and $700 \mathrm{~nm})$ with an integrating nephelometer (TSI, model 3563), which integrates light scattered by particles at scattering angle between 7 and $170^{\circ}$ relative to the incident and scattered radiation. The instrument operated at a volumetric flow rate of $30 \mathrm{~L} \mathrm{~min}^{-1}$ and the data were acquired at $1 \mathrm{~s}$ time resolution. The instrument was calibrated with free-particle air and high-purity $\mathrm{CO}_{2}$ prior to and after the campaign. Uncertainty in $\sigma_{\text {scat }}$ measured with the nephelometer is estimated to be $5 \%$ (Muller et al., 2011a). Measured values were corrected for the angular truncation error in the nephelometer measurements at angles smaller than $7^{\circ}$ and greater than $170^{\circ}$ as described in Sect. 2.3.2.

The particle extinction coefficient $\left(\sigma_{\text {ext }}\right)$ was measured with a cavity attenuated phase shift particle light extinction monitor (CAPS-PMex, Aerodyne Research) operated at the wavelength of $530 \mathrm{~nm}$. The instrument relies on measuring the average time spent by the light within the sample cell that has an optical path length of $1-2 \mathrm{~km}$. The sampling volumetric flow rate was $0.85 \mathrm{~L} \mathrm{~min}^{-1}$ and data were processed with a time resolution of $1 \mathrm{~s}$. Uncertainty in $\sigma_{\text {ext }}$ measured with the CAPS is estimated to be $3 \%$ (Massoli et al., 2010).

\subsection{Aerosol data analysis}

Figure 2 depicts the iterative procedure used to retrieve the aerosol size distribution and optical parameters relevant to this paper. We focused our attention on aerosol parameters 
used in climate models for calculating the direct and semidirect aerosol radiative effects.

- The complex refractive index $\widetilde{n}$ defined as $n_{\mathrm{r}}-\mathrm{i} n_{\mathrm{i}}$, where $n_{\mathrm{r}}$ and $n_{\mathrm{i}}$ are the real and imaginary part representing the particle scattering and absorption properties respectively.

- The single scattering albedo $\omega_{0}$ (unitless) representing the balance between the scattering and the absorbing properties and defined as

$$
\omega_{0}(\lambda)=\frac{\sigma_{\text {scat }}(\lambda)}{\sigma_{\text {ext }}(\lambda)},
$$

where $\sigma_{\text {scat }}$ is the aerosol scattering coefficient (expressed in $\mathrm{Mm}^{-1}=10^{-6} \mathrm{~m}^{-1}$ ), $\sigma_{\text {ext }}$ the aerosol extinction coefficient $\left(\mathrm{Mm}^{-1}\right)$ and $\lambda$ the wavelength $(\mathrm{nm})$.

- The asymmetry parameter $g$ (unitless) describing the angular distribution of the scattered radiation and defined as

$$
g(\lambda)=\frac{1}{2} \int_{0}^{\Pi} \cos (\Phi) \sin (\Phi) P(\Phi, \lambda) \mathrm{d} \Phi,
$$

where $P(\Phi, \lambda, \lambda)$ is the scattering phase function and $\Phi$ is the scattering angle.

- The mass extinction efficiency $k_{\text {ext }}\left(\mathrm{m}^{2} \mathrm{~g}^{-1}\right)$ representing the total light extinction per unit mass concentration of aerosol and calculated as

$$
k_{\mathrm{ext}}(\lambda)=\frac{\sigma_{\mathrm{ext}}(\lambda)}{C_{\mathrm{m}}},
$$

where $C_{\mathrm{m}}$ is the aerosol mass concentration $\left(\mu \mathrm{g} \mathrm{m}^{-3}\right)$.

In this study, we have decided to neglect the non-sphericity of mineral dust since the sphere model has been shown to produce negligible errors when computing radiative fluxes and flux related quantities, i.e. aerosol optical depth (AOD), $\omega_{0}$ and $g$ (Mishchenko et al., 1995). Because we only investigate angular-integrated properties and for sake of comparison with the large majority of field data published so far, in this paper we only perform calculations in the spherical approximation.

\subsubsection{Assessment of aerosol size distributions}

The particle size distribution was derived from the SMPS, UHSAS, GRIMM and FSSP-300. For size distributions measured by SMPS, the electrical mobility $D_{\mathrm{m}}$ and the geometric particle diameters $D_{\mathrm{g}}$ are related by the dynamic shape factor (DeCarlo et al., 2004):

$D_{\mathrm{g}}=\frac{D_{\mathrm{m}}}{\chi}$.
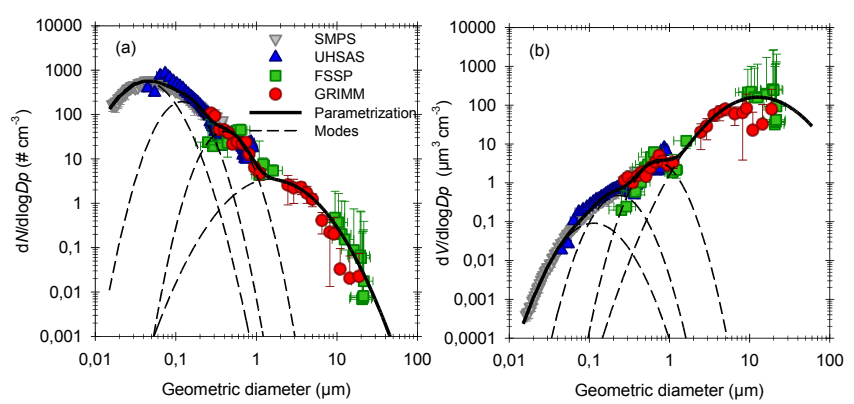

Figure 3. Number (a) and volume (b) size distributions obtained by the SMPS (grey), UHSAS (blue), FSSP (green) and GRIMM (red) during the flight F35, including refractive index corrections for $\widetilde{n}=1.53-0.004 i$. Vertical errors bars indicate 1 standard deviation of the data during the SLRs. Horizontal errors bars display the bin sizing uncertainties of the instruments. The dark line represents the parameterized fit with a sum of four log-normal modes (shown in dashed lines).

The dynamic shape factor $\chi$ depends on the shape of the particles (Hinds, 1999). In this study, we have decided to neglect the non-sphericity of mineral dust to maintain retrieval conditions similar to those of previous literature studies on dust in the source region. Henceforth, $\chi$ was set to unity.

Optical sizing instruments (i.e. UHSAS, GRIMM, FSSP300) measure the amount of light scattered by a single particle and convert this into a geometric particle size. This conversion depends on the complex refractive index of the aerosol, as well as on the optical geometry and the laser wavelength of the instrument. The correction procedure used the Mie scattering theory for homogeneous spheres with known complex refractive index (Bohren and Huffman, 1983).

As discussed by Reid et al. (2003), the conversion of scattered light into particle size can lead to ambiguity in the sizing of the coarse mode diameters. If the light intensity response of the optical sizing instruments is non-unique it can lead to oversizing of larger particles. This happens mostly for forward scattering probes, such as the FSSP-300, as demonstrated in Fig. S1 in the Supplement showing a flattening in the scattering cross section curves integrated over the FSSP-300 scattering angle range $\left(3-15^{\circ}\right)$ between 2 and $10 \mu \mathrm{m}$ diameter. For the GRIMM 1.129 scattering angles $\left(30-150^{\circ}\right)$, the scattering cross section is unique with size, except between 1.5 and $2 \mu \mathrm{m}$ where an inflection point can be seen. During ADRIMED, systematic differences in the size distributions measured by the FSSP-300 and the GRIMM were observed around $2 \mu \mathrm{m}$. Given the response curves in Fig. S1, data between $2-10 \mu \mathrm{m}$ and $1.5-2 \mu \mathrm{m}$ diameter from the FSSP-300 and the GRIMM respectively were not considered in this paper.

Figure 3 presents an example of size distributions measured in a dust plume by the different instruments. As will be discussed below, the value of $\widetilde{n}=1.53-0.004 i$ at $530 \mathrm{~nm}$ 
was the most appropriate to restitute both scattering and extinction coefficient and therefore we present results using this value in Fig. 3. Overall, the comparison between different instruments shows good consistency, giving credence to the measurements and the choice of refractive index and dynamic shape factor.

The resulting number and volume size distributions were parameterized by fitting four log-normal distributions, as

$$
\begin{aligned}
\frac{\mathrm{d} N}{\mathrm{~d} \log D_{\mathrm{p}}}= & \sum_{i=1}^{4} \frac{N_{\mathrm{tot}, i}}{\sqrt{2 \pi} \log \sigma_{i}} \\
& \exp \left[-\frac{\left(\log D_{\mathrm{p}}-\log D_{\mathrm{p}, \mathrm{g}, i}\right)^{2}}{2\left(\log \sigma_{i}\right)^{2}}\right], \\
\frac{\mathrm{d} V}{\mathrm{~d} \log D_{\mathrm{p}}}= & \sum_{i=1}^{4} \frac{N_{\mathrm{tot}, i \frac{\pi}{6} D_{\mathrm{p}}^{3}}}{\sqrt{2 \pi} \log \sigma_{i}} \\
& \exp \left[-\frac{\left(\log D_{\mathrm{p}}-\log D_{\mathrm{p}, \mathrm{g}, i}\right)^{2}}{2\left(\log \sigma_{i}\right)^{2}}\right],
\end{aligned}
$$

where each mode $i$ is characterized by the integrated number concentration $N_{\text {tot }}, i$, the geometric median diameter $D_{\mathrm{p}, \mathrm{g}, i}$ and the geometric standard deviation $\sigma_{i}$ (i.e. Fig. 3).

To provide a synthetic representation of the particle number size distributions, the effective particle $D_{\text {eff }}$ was calculated as

$$
D_{\text {eff }}=\frac{\int D_{\mathrm{p}}^{3} \frac{\mathrm{d} N}{\mathrm{~d} D_{\mathrm{p}}} \mathrm{d} D_{\mathrm{p}}}{\int D_{\mathrm{p}}^{2} \frac{\mathrm{d} N}{\mathrm{~d} D_{\mathrm{p}}} \mathrm{d} D_{\mathrm{p}}} .
$$

$D_{\text {eff }}$ has been estimated separately on the fine and coarse fractions in the size ranges $0.053-1 \mu \mathrm{m}$ (referred to as $D_{\text {eff,f }}$ thereafter) and $1-20 \mu \mathrm{m}$ (referred to as $D_{\text {eff,c }}$ ) respectively.

\subsubsection{Assessment of aerosol optical properties}

An iterative procedure was used to derive $\widetilde{n}, \omega_{0}, g$ and $k_{\text {ext }}$ at $530 \mathrm{~nm}$ and correct $\sigma_{\text {scat }}$ for the angular truncation error (i.e. Fig. 2). The parameterized size distributions were used as input for the Mie scattering calculations (Bohren and Huffman, 1983), which were done by varying stepwise the real part of the complex refractive index $n_{\mathrm{r}}$ from 1.33 to 1.60 and the imaginary part of the complex refractive index $n_{\mathrm{i}}$ from 0.000 to 0.020 . $\widetilde{n}$ was assumed to be constant with particle size and have thus to be regarded as an effective value for the entire particle population. $\sigma_{\text {scat }}$ was adjusted to the CAPS operation wavelength of $530 \mathrm{~nm}$ by using the following equation:

$\AA\left(\lambda_{1}, \lambda_{2}\right)=-\frac{\ln \left(\sigma_{\text {scat }}\left(\lambda_{1}\right) / \sigma_{\text {scat }}\left(\lambda_{2}\right)\right)}{\ln \left(\lambda_{1} / \lambda_{2}\right)}$,

where $\AA$ represents the spectral dependence of the scattering coefficient and $\lambda_{1}$ and $\lambda_{2}$ are the wavelength intervals. $\AA$ is often used as a qualitative indicator of aerosol particle size or fine mode fraction (Seinfeld and Pandis, 1998). Typically, it is lower than $\sim 0.5$ for aerosols dominated by coarse particles, such as mineral dust or sea salt, but it is higher than 1 for fine particles, such as pollution particles or biomass burning. The calculated values of $\sigma_{\text {scat }}(530 \mathrm{~nm})$ and $\sigma_{\text {ext }}(530 \mathrm{~nm})$ were compared to that measured by the nephelometer and the CAPS, and values having the closest agreement within the measurement error bars were chosen as the best estimate.

The in-aircraft aerosol instruments sampled through isokinetic and isoaxial aerosol inlets. The nephelometer and GRIMM were set up behind the AVIRAD inlet, while the CAPS, SMPS and SP2 were set up behind the Community Aerosol Inlet (CAI). Particle loss can occur both as a result of the inlet aspiration efficiency and the transport losses in the pipework between the inlet and the instruments. The cut-off diameter, at which the passing efficiency of the inlet equals $50 \%$, was determined by a set of wind-tunnel experiments (unpublished data). The passing efficiency was determined as the ratio of the particle number concentration measured by GRIMM optical counters behind the sampling lines of the AVIRAD and CAI inlets to the particle number concentration measured in the main flow of the wing tunnel where the air speed was $93 \mathrm{~m} \mathrm{~s}^{-1}$ as the cruise speed of the ATR42. Monodisperse polystyrene latex spheres of 0.6, 1.2, 4.6, 7.9 and $11 \mu \mathrm{m}$ diameter (Duke Scientifics, Thermo Sci.) and polystyrene divinylbenzene spheres of diameter varying between 1 and $35 \mu \mathrm{m}$ in diameter (also purchased from Duke Scientifics) were first diluted and then put in a reservoir connected to a peristaltic pump. The pump tubing was connected to a pneumatic spinning disk (SPIDI) in order to spray a large amount of droplets from the solution, some droplets having a particle incorporated. An air mover was mounted beneath the SPIDI and thus the droplets were rapidly evaporated. The particle size-dependent passing efficiency of the AVIRAD and CAI sampling inlets shown in Fig. S2 indicates that the cut-off diameter value, expressed as optical equivalent, is $12 \mu \mathrm{m}$ for the AVIRAD inlet and $5 \mu \mathrm{m}$ for the CAI.

To assess the impact of the inlets sampling efficiency on the measured optical properties, Mie scattering calculations were performed to estimate $n_{\mathrm{r}}, n_{\mathrm{i}}, \omega_{0}, g$ and $k_{\mathrm{ext}}$ using either the full size distribution or the size distribution measured behind the aircraft inlets. For $\omega_{0}, g$ and $k_{\text {ext }}$, we considered a fixed refractive index of $1.52-0.003 i$, reflective of the values observed for Saharan dust in the source region (Schladitz et al., 2009; Formenti et al., 2011a; Ryder et al., 2013a). The discrepancies between $\omega_{0}, g$ and $k_{\text {ext }}$, including or not larger particle sizes, were used to estimate the errors associated with the inlets sampling efficiency. For $n_{\mathrm{r}}$ and $n_{\mathrm{i}}$, we estimated the difference between $\tilde{n}$ derived from the iterative procedure described above (i.e. Fig. 2) using the full size distribution as input parameter and that obtained from the size distribution measured behind the aircraft inlets. The absolute errors associated with $\omega_{0}, g$ and $k_{\text {ext }}$ due to the passing efficiencies of the inlets were estimated to be $0.02,0.002,0.04$, 0.05 and 0.08 respectively, which is in the range covered by 
the measurements uncertainties of both optical parameters and size distributions.

\subsection{Ancillary products}

Weather Research and Forecasting (WRF; Skamarock et al., 2008) simulations were performed to investigate the meteorological conditions and the turbulence within the dust layers. The WRF model is operational at the Department of Physics of the University of Genoa, Italy, in a three-domain configuration. In particular, the simulations on the parent domain, covering the entire Mediterranean basin with a horizontal grid spacing of $10 \mathrm{~km}$, have been considered for the present paper. Initial and boundary conditions were generated from the operational global model GFS (Environmental Modeling Center, 2003) outputs $(0.5 \times 0.5$ square degree $)$. More details about the modelling chain and the model setup are given in Bove et al. (2014), Cassola et al. (2015) and Mentaschi et al. (2015).

As a complement, synoptic conditions and sea level pressure composite anomalies over the Mediterranean basin during the campaign were analysed using reanalysis data sets, such as the NCEP/NCAR Reanalysis (Kalnay et al. 1996) and the NCEP Climate Forecast System (CFS) reanalysis (Saha et al., 2010).

Source regions and atmospheric transport times of the dust plumes were determined through the combination of satellite products and backward trajectory analysis. The potential source regions active during the observational period were identified using the images from SEVIRI on board the MSG satellite. The NOAA HYbrid Single-Particle Lagrangian Integrated Trajectory Model (HYSPLIT, http://www.arl.noaa. gov/HYSPLIT.php) using the Global Data Assimilation System (GDAS) meteorological input was used to calculate whether an air mass sampled by the aircraft could have originated from one of the identified active dust sources. Backward trajectories were initialized using the time and the location when the aircraft intercepted the air mass and were extended for up to 5 days prior the measurement. Backward trajectory calculations were performed at the beginning, middle and end of each SLR to check the origin and transport pathway of the air masses sampled by the aircraft through the measurements. We then operationally define the dust age as the time elapsed since the calculated air mass trajectory leave the ground where an active source was detected and up to the time of sampling by the aircraft.

\section{Results}

\subsection{Identification of the dust source region and transport pathway}

During the ChArMEx/ADRIMED campaign, the synoptic situation was characterized by a "dipolar" sea level pressure anomaly pattern, with positive anomalies in the western
Mediterranean and negative ones in the eastern part of the basin, as illustrated in Fig. 4 (left panel). While this situation induced stronger and more frequent than normal northwesterly winds over the Sardinia and Sicily channels, the average conditions at mid-atmospheric levels during the campaign were closer to climatological ones (Fig. 4, right panel). Moulin et al. (1998) have documented the frequency of dust episodes across the Mediterranean Sea, summer occurrences are quite frequent.

The synoptic conditions during each of the nine flights described in Fig. 1 and Table 1 are summarized in Figs. S3 and $\mathrm{S} 4$ in the Supplement, where sea level pressure and $500 \mathrm{hPa}$ geopotential height are shown. A low-pressure system can be found over the Atlantic on 16 June, moving towards the Iberian Peninsula, while a subtropical ridge extends from North Africa to central Mediterranean. This situation induced a strong south-southwesterly flow, firstly towards southern Iberia and western Mediterranean (16-17 June), then extending eastwards and reaching Corsica on the subsequent days, favouring dust transport from the Saharan region. This is quite evident from Fig. S5, showing $700 \mathrm{hPa}$ wind and relative humidity maps from the WRF model. Figure 1 shows the likely sources regions for dust sampled during the flights, identified from HYSPLIT simulation and MSGSEVIRI satellite products. Mineral dust were most likely uplifted from southern Morocco and southern Algeria and were sampled during flights F29, F30, F31 and F32 after 3.54.5 days of transport.

On 19-20 June the remnants of the aforementioned low are still visible as an upper-level trough over the western Mediterranean (Fig. S5), triggering meridional transport at higher levels from North Algeria/Tunisia towards the Sardinia and Sicily channels. This is confirmed by backward trajectory and satellite product analyses showing that the dust sampled during the flight F33-34 travelled 1 to 5 days from North Algeria/Tunisia before its sampling (not shown). On 28 June during flight F38, an upper-level low is found over the Alps and central Europe, inducing a westerly flow from Tunisia where mineral dust were most likely uplifted towards Sicily at $700 \mathrm{hPa}$ (Fig. S6), while the surface high pressure over eastern Atlantic and Iberia is associated with northwesterly winds at lower levels throughout most of the central Mediterranean. Finally, the situation during the last flight F42 (3 July) was characterized by a modest depression over Iberia, while the Azores anticyclone extended towards the Mediterranean. As a consequence, upper-level winds were mainly southwesterly over North Africa, veering to westerly or northwesterly over the Sardinia and Sicily channels, thus contributing to dust transport in the area. We estimate that mineral dust originating from South Morocco and Tunisia was transported for 3.5 days before sampling.

The identification of the dust source regions was confirmed by the measurements of the elemental composition. Overall, $\mathrm{Si} / \mathrm{Al}$ ranged between 2.4 and 2.7 and $\mathrm{Fe} / \mathrm{Ca}$ between 0.3 and 0.7 in the samples collected during 

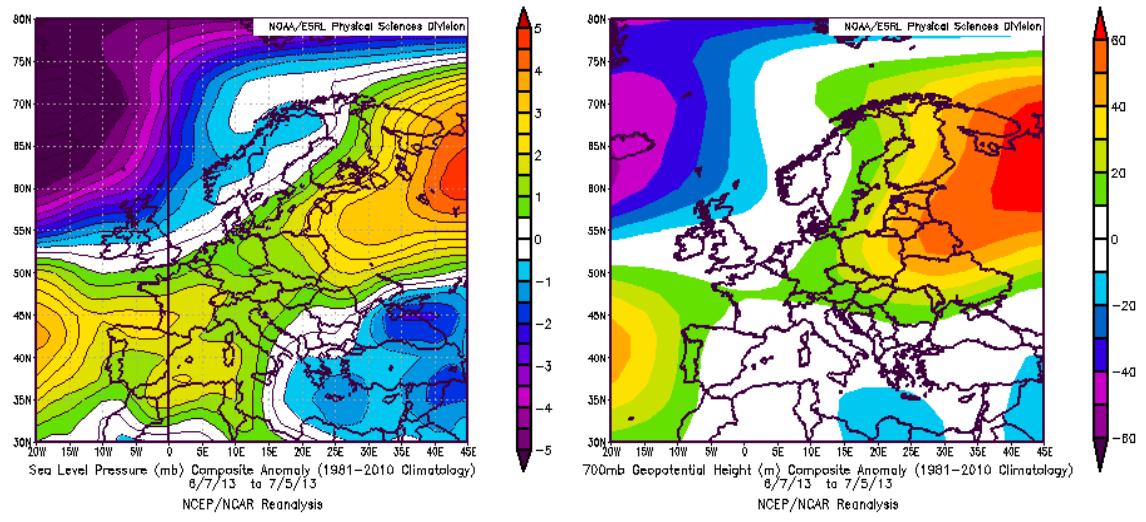

Figure 4. Sea level pressure in hPa (left) and $700 \mathrm{hPa}$ geopotential height in metres (right) composite mean anomalies over the period from 7 June to 5 July 2013 with respect to the 1981-2010 climatology obtained from the NCEP/NCAR Reanalysis (images provided by the NOAA/ESRL Physical Sciences Division, Boulder Colorado, from their web site at http://www.esrl.noaa.gov/psd/).

ChArMEx/ADRIMED. This is consistent with values previously reported for mineral dust originating from Algeria, Tunisia and Morocco (Scheuvens et al., 2013; Formenti et al., 2014). The identified emission areas also correspond to known source regions such as the Grand Erg Occidental at the border between Algeria and Morocco, the Mekkeranne in Algeria and the Chott El Jerïd in Tunisia (Ginoux et al., 2012).

\subsection{Vertical distribution of mineral dust}

Figure 5 shows the vertical profiles of the aerosol scattering coefficient $\sigma_{\text {scat }}$ at $\lambda=450,550$ and $700 \mathrm{~nm}$, the total particle number concentration in the submicron $\left(N_{\text {fine }} ; 5 \mathrm{~nm}<D_{\mathrm{p}}<1 \mu \mathrm{m}\right)$ and the supermicron $\left(N_{\text {coarse }}\right.$; $D_{\mathrm{p}}>1 \mu \mathrm{m}$ ) size ranges, and the vertical distribution of the scattering Angstrom exponent $\AA$ calculated between 450 and $770 \mathrm{~nm}$. The top height of the boundary layer $\left(Z_{\mathrm{b}}\right)$ and the wind shear level $\left(Z_{\mathrm{s}}\right)$ are also indicated in Fig. 5 by a solid and a dashed line respectively. All the vertical profiles were characterized by a weak and positive gradient of the potential temperature, characteristic of a stratified atmosphere (Fig. S7). The top height of the boundary layer was identified as the height at which the temperature profile showed the highest discontinuity and the water vapour mixing ratio decreased the most rapidly. The shear level was determined from the sudden increase in wind speed and change in wind direction (Fig. S7).

Mineral dust was observed above the boundary layer in layers extending from $1 \mathrm{~km}$ to more than $6 \mathrm{~km}$ a.s.l. (Fig. 5). The presence of mineral dust within the boundary layer was attested neither by chemical analyses nor with the backtrajectories analyses, which revealed that in the 5 days prior sampling, low-level air masses originated from the European continent or recirculated within Mediterranean basin. The transport of mineral dust in the free troposphere up to $9 \mathrm{~km}$ in altitude is a common observation in the Mediterranean re- gion, as previously reported by lidar measurements (Gobbi et al., 2000; Dulac and Chazette, 2003; Mona et al., 2006; Di Iorio et al., 2009; Gómez-Amo et al., 2011). Such high altitudes may be linked to the strong vertical convective processes over the dust source regions, which lift dust particles at high atmospheric levels (Flamant et al., 2007; Papayannis et al., 2008; Cuesta et al., 2009).

The dust vertical structures showed an important variability. Complex and stratified structures were observed depending on the position of $Z_{\mathrm{b}}$ and $Z_{\mathrm{s}}$. During the campaign, the wind shear level was equal to or higher than the top of the boundary layer.

When $Z_{\mathrm{b}}$ and $Z_{\mathrm{s}}$ coincided (F30, F31, F32, F38), the dust vertical structure was characterized by a single and rather homogeneous layer. It is noteworthy that apparently similar thermodynamical situations displayed a different spectral dependence of the scattering coefficient, as for example is the case above the boundary layer for flights F32 $(\AA \sim 0.3)$ and F38 $(\AA \sim 0.9)$, pointing out differences in the particle type. The values of $\AA$ observed during the flight F38 were higher than the values of $\sim 0.5$ reported for Saharan dust in source region (McConnell et al., 2008a; Muller et al., 2011b) but lower than values of $\AA>1$ reported for air masses dominated by pollution aerosols in the western Mediterranean basin (Di Biagio et al., 2015). It is reasonable to suppose that the profile F38 reflects a situation where desert dust was mixed with pollution particles. This is confirmed by the 5-day backward trajectories (Fig. 6a), which indicate an air parcel coming from Europe and travelling at least 3 days above the Mediterranean Sea within the boundary level before its uplift over Tunisia.

When $Z_{\mathrm{s}}$ was higher than $Z_{\mathrm{b}}(\mathrm{F} 33, \mathrm{~F} 34, \mathrm{~F} 35)$, mineral dust was found in two distinct layers below and above $3 \mathrm{~km}$ a.s.l. The 5-day backward trajectories suggest that these dust layers originated from different dust source regions (Fig. 1 and Table 1). An example is given by the flight F35 (Fig. 6b) for which the above- $3 \mathrm{~km}$ dust layer originated from central Algeria and was carried by northern flow to Lampedusa in 

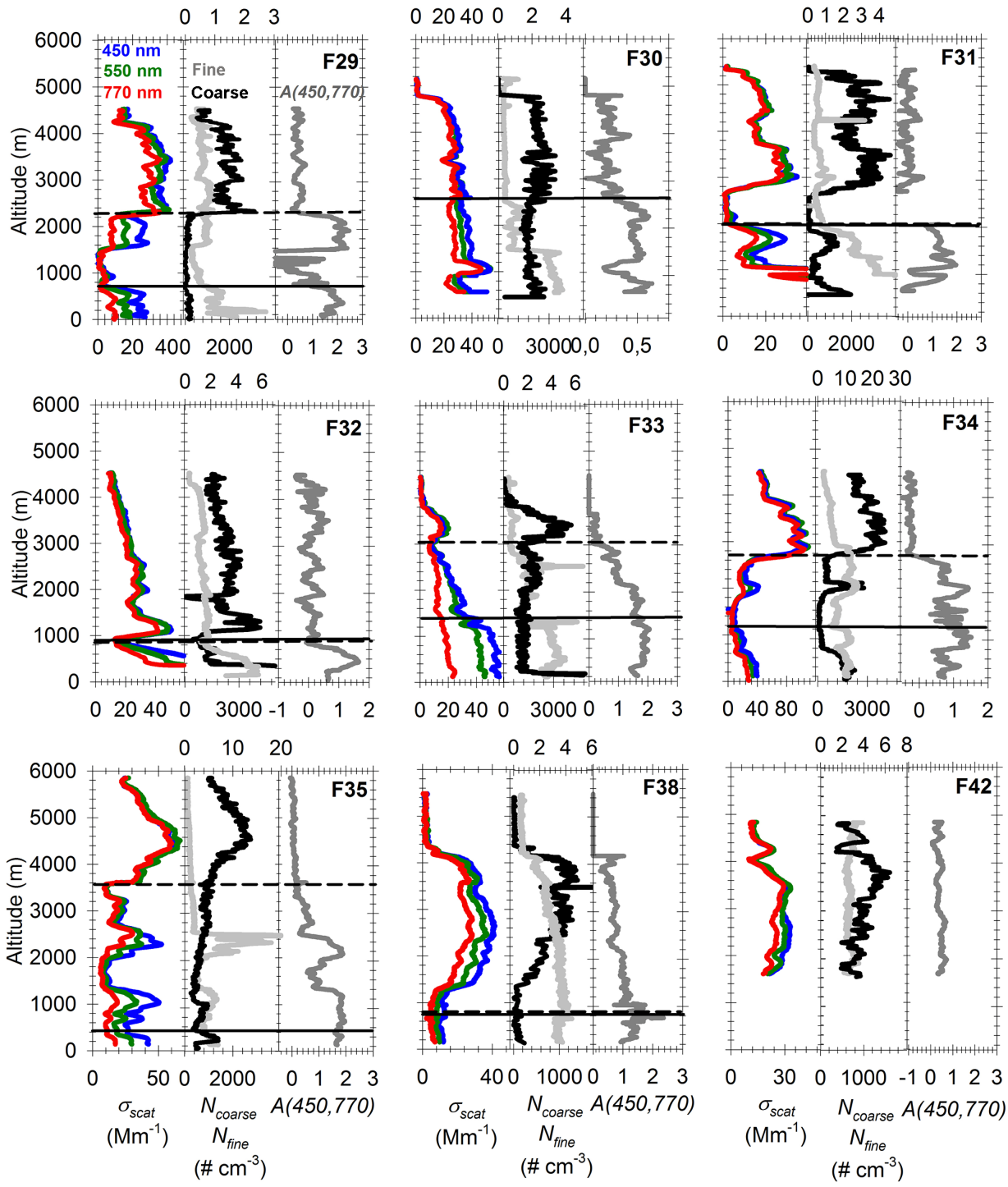

Figure 5. Vertical profiles of the aerosol scattering coefficient $\sigma_{\text {scat }}$ at $\lambda=450,550$ and $770 \mathrm{~nm}$ (blue, green and red), the particle number concentration in the submicron $N_{\text {fine }}$ (light grey) and the supermicron $N_{\text {coarse }}$ (dark) size ranges and the scattering Ångström exponent $\AA$ calculated between 450 and $770 \mathrm{~nm}$ (dark grey). $N_{\text {coarse }}$ is plotted using the upper horizontal axis. The top of the boundary-layer $Z_{\mathrm{b}}$ and the wind shear level $Z_{\mathrm{s}}$ are indicated by a horizontal and dashed line respectively. The height of $Z_{\mathrm{b}}$ was situated below the minimum flight level in F30 and F42. The height of $Z_{\mathrm{S}}$ was situated below the minimum flight level in F42. Data were corrected for standard temperature and pressure using $T=20^{\circ} \mathrm{C}$ and $P=1013.25 \mathrm{hPa}$.

3.5 days, whereas the below- $3 \mathrm{~km}$ dust layer was transported from the southeastern Morocco-southwestern Algeria border region by a westerly flow within 3 days. Similar structure with multilayering of the Saharan dust corresponding to air masses from different dust source regions was previously observed by lidar measurements in the Mediterranean region (Hamonou et al., 1999; Guerrero-Rascado et al., 2008).

Regardless of the thermodynamical structure of the atmosphere, the aerosol vertical profiles revealed a clear vertical variability of the contribution of fine mode particles in the dust layers. The values of $N_{\text {fine }}$ and $\AA$ were gener- ally below 1000 no. $\mathrm{cm}^{-3}$ and 0.5 respectively in dust layers above $3 \mathrm{~km}$ a.s.l. In contrast, $N_{\text {fine }}$ and $\AA$ were up to 4000 no. $\mathrm{cm}^{-3}$ and 2.2 respectively in the dust layers below $3 \mathrm{~km}$ altitude (Fig. 5). These observations suggest that either the dust plumes carried more fine particles during transport below $3 \mathrm{~km}$ altitude or dust particles in the fine mode exhibited a vertical gradient.

\subsection{Size distribution of the dust plumes}

Particle number size distributions classified as a function of altitude are shown in Fig. 7. Table 3 presents the average 

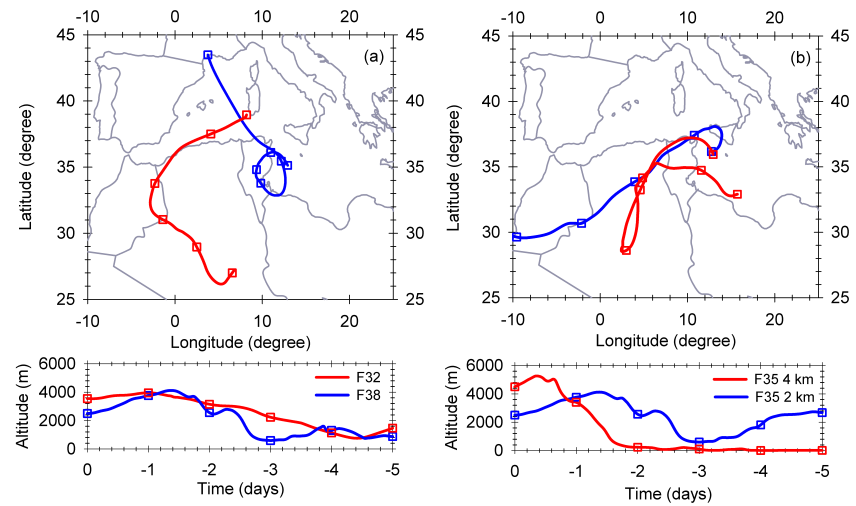

Figure 6. Five-day backward trajectories calculated for (a) flights F32 and F38 and (b) flight F35 arriving at 2 and $4 \mathrm{~km}$ a.s.l. altitudes in blue and red respectively.

characteristics of the parameterized four-modal number size distributions.

In the fine mode particle size range, the size distributions showed three modes around 80, 120 and $320 \mathrm{~nm}$ (Fig. 7a). For particles smaller than $300 \mathrm{~nm}$, the shapes of the size distributions in the dust layer and in the boundary layer were quite similar. As particles in this size range mostly reflect anthropogenic influences from near or distant sources (Birmili et al., 2010), this indicates that the pollution plumes from the surface were exported above the boundary layer and mixed with the dust layers. The particle size distributions in the dust layers above $3 \mathrm{~km}$ followed a similar pattern as in the dust layers below $3 \mathrm{~km}$ but number concentrations 2 times smaller were observed for the modes at 80 and $120 \mathrm{~nm}$, suggesting that the concentration of pollution particles varied with the altitude. For particles between $300 \mathrm{~nm}$ and $1 \mu \mathrm{m}$, the particle size distributions were reasonably constant for dust layers at various altitudes. Gomes et al. (1990) found dust particles as small as $300 \mathrm{~nm}$ diameter in Algeria, which was also confirmed by Kaaden et al. (2008) and Kandler et al. (2009) in Morocco. The decrease of $N_{\text {fine }}$ with altitude (i.e. Fig. 5) was therefore most likely due to the larger concentration of sub$300 \mathrm{~nm}$ pollution particles transported in the dust plumes below $3 \mathrm{~km}$ altitude. The fact that an identical median diameter $D_{\mathrm{p}, \mathrm{g}}$ was used to parameterize the number size distributions in the fine mode for below- and above- $3 \mathrm{~km}$ layers (Table 3 ) and the prevalence of a sub-300 nm particles in the below$3 \mathrm{~km}$ dust layer (Fig. 7a) might also reflect that the mixing between the pollution and the dust plumes was mostly external in the fine mode.

In the coarse mode, a modal diameter of the number size distribution between 1.3 and $2.0 \mu \mathrm{m}$ was observed indiscriminate of dust altitude. This indicates that the dust layers transported over the Mediterranean basin were well mixed vertically in terms of coarse particle population, as previously observed by Weinzierl et al. (2011) for mineral dust after short-range transport over the eastern Atlantic Ocean. Con- versely, the number concentration of large dust particles decreased with increasing altitude for freshly uplifted Saharan dust (Weinzierl et al., 2009; Ryder et al., 2013a). There is some evidence suggesting that the good vertical mixing of the dust plumes occurs during the first day following the dust uplifted (Ryder et al., 2013b). Turbulent fluxes within the dust layer might be responsible for the vertical distribution of the dust aerosols becoming more homogeneous in terms of coarse mode particles as the dust ages (Rosenberg et al., 2014). Particles in the coarse mode showed a large flightto-flight variability with number concentrations varying by more than 1 order of magnitude. This is quite evident in Fig. 7b showing the conversion of number size distributions into volume size distributions. This variation in concentration might reflect the wide range of dust event encountered during the campaign in terms of source regions, time of transport and meteorological conditions.

The spread of volume size distributions obtained during ADRIMED overlaps with those measured during other airborne campaigns close to dust source regions (AMMA, FENNEC and SAMUM-1) in the coarse mode size range (Fig. 7c). Effective diameters of the coarse mode $D_{\text {eff,c }}$ (i.e. estimated in the size $1-20 \mu \mathrm{m}$ as defined in Eq. 7) ranged from 3.8 to $14.2 \mu \mathrm{m}$ during ADRIMED, which is in the range of magnitude of the mean values of $3.8,8.8$ and $7.4 \mu \mathrm{m}$ obtained during AMMA, FENNEC and SAMUM-1 respectively (Formenti et al., 2011b; Ryder et al. 2013a; Weinzierl et al., 2011). Balloon-borne observations during ADRIMED also showed the presence of large particles of more than $15 \mu \mathrm{m}$ in diameter inside dust plumes transported over the Mediterranean basin (Renard et al., 2015). Contrastingly, fewer particles larger than $10 \mu \mathrm{m}$ were counted after shortrange transport over the eastern Atlantic Ocean in the Cape Verde region during SAMUM-2 with respect to the other campaigns. $D_{\text {eff,c }}$ around $3.2 \mu \mathrm{m}$ was found in the dust layers during SAMUM-2 (Weinzierl et al., 2011).

\subsection{Optical properties of the dust plumes}

Figure $8 \mathrm{a}-\mathrm{b}$ show the vertical distribution of the real and imaginary parts of the refractive index $\widetilde{n}$. Within the dust plumes, $\widetilde{n}$ ranged from 1.50 to 1.55 for the real part and remained below 0.005 for the imaginary part. Since $\widetilde{n}$ is related to the aerosol chemical composition (Liu and Daum, 2008), it is expected to be influenced by the mixing rate of the dust plume with pollution particles. We thus plotted the values of $\widetilde{n}$ as a function of $\AA$. Besides not displaying significant variation with the altitude, the values of $\widetilde{n}$ did not show any dependence on $\AA$. The results obtained during ADRIMED have been compared in Fig. 8 with data in the literature for Saharan dust in or near sources. For both the real and imaginary parts, our estimates of $\tilde{n}$ fall within the range of variability (1.51-1.57 and 0.0001-0.0046 for the real and the imaginary parts respectively) documented in source regions (Schladitz et al., 2009; Formenti et al., 2011a; Ryder et al., 2013b). This 

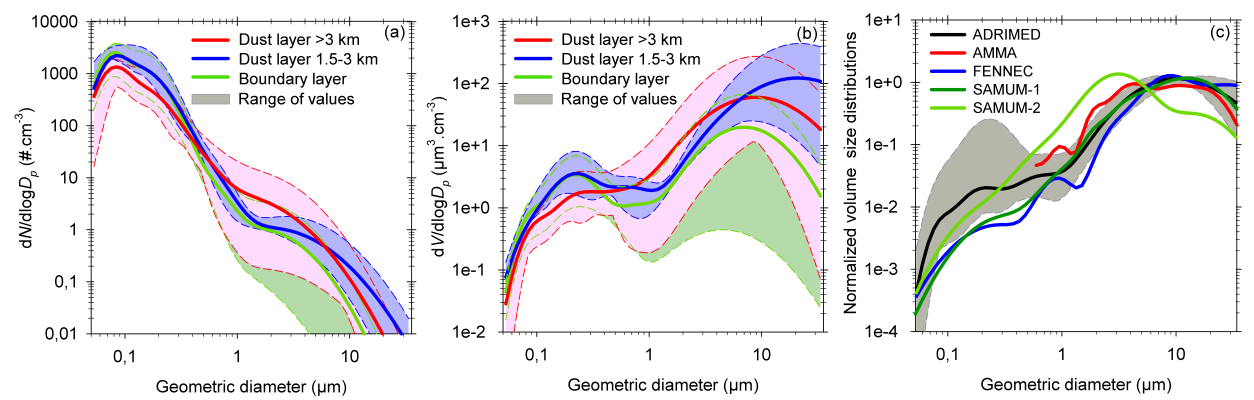

Figure 7. Particle size distributions obtained in the dust layers during ADRIMED for (a) number distribution, (b) volume distribution and (c) volume distribution normalized by the total volume concentration. In panels (a) and (b), size distributions are classified as a function of the altitude of the layer: dust layer above $3 \mathrm{~km}$ a.s.l. (red), dust layer between 1.5 and $3 \mathrm{~km}$ a.s.l. (blue) and the boundary layer below $1 \mathrm{~km}$ (green). The shading represents the range throughout the campaign. In panel (c), the mean (dark line), minimum and maximum normalized size distributions (grey shading) observed above $1.5 \mathrm{~km}$ during the ChArMEx/ADRIMED campaign are compared with those observed in the source region during the airborne campaigns AMMA (red line, Formenti et al., 2011a), FENNEC (blue line; Ryder et al., 2013b) and SAMUM-1 (dark green line; Weinzierl et al., 2009), as well as with measurements at Cape Verde region during SAMUM-2 campaign (light green line; Weinzierl et al., 2011). The AMMA curve (Formenti et al., 2011) is curtailed to $0.3 \mu \mathrm{m}$ since there was no measurement below this size during the campaign.

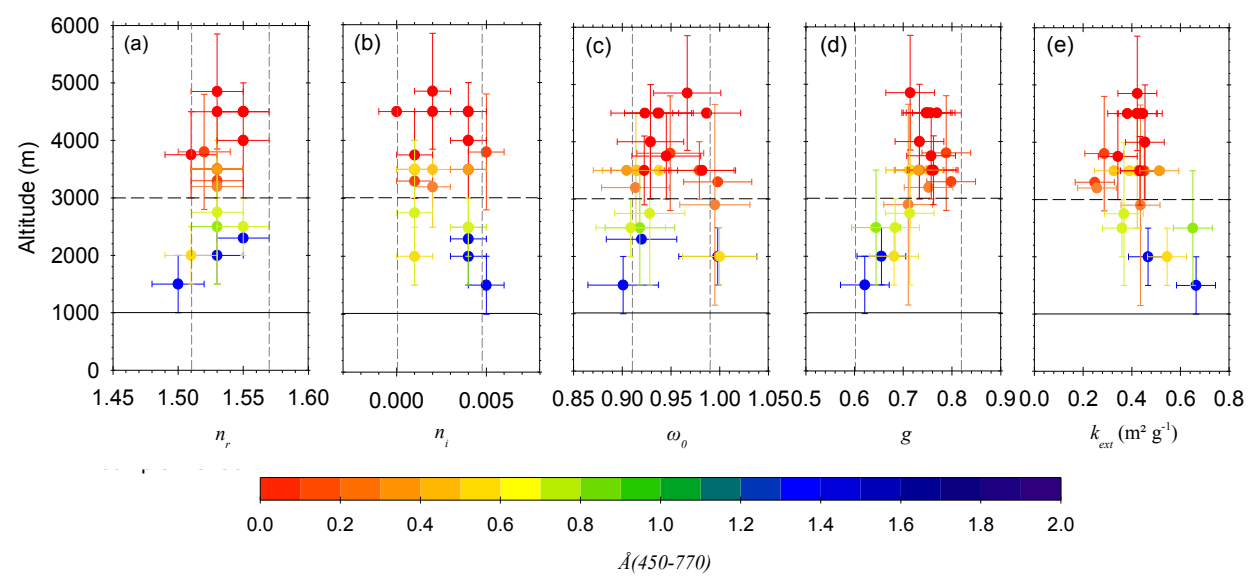

Figure 8. Scatter plots showing (a) the real part of the complex refractive index $n_{\mathrm{r}}$, (b) the imaginary part of the complex refractive index $n_{\mathrm{i}}$, (c) the single scattering albedo $\omega_{0}$, (d) the asymmetry parameter $g$ and (e) the mass extinction efficiency of aerosols $k_{\text {ext }}$ all at $\lambda=530 \mathrm{~nm}$ as a function of the altitude from all SLRs and vertical profiles within the dust layers measured during the campaign. The altitude indicated for vertical profiles refers to the middle of the layer. Horizontal error bars display the uncertainties of the parameters. Vertical error bars indicate the altitude range used to calculate each data point. Broad classifications of the above- $3 \mathrm{~km}$ dust layer and the below- $3 \mathrm{~km}$ dust layer are shown in horizontal lines. Vertical dashed lines indicate the range of values obtained in dust source regions. The maximum value of $k_{\text {ext }}$ reported in the literature for dust in source regions is above $0.8 \mathrm{~m}^{2} \mathrm{~g}^{-1}$.

variability was attributed to the variability of the mineralogical composition of dust originating from diverse source regions (Kandler et al., 2009; Petzold et al., 2009). Our data do not show any clear dependence of $\tilde{n}$ on dust source region either (not shown), which is consistent with the limited regional variability of the dust optical properties found 12 days after emissions in Africa by Formenti et al. (2014) from aircraft measurements. This is probably a consequence of the mixing of dust plumes from various active sources occurring during transport shortly after emission. A number of uncertainties in our identification of dust source region are associated with the employed methodology. The trajectory error associated with calculation of back trajectories from HYSPLIT reaches $15-30 \%$ of the travel distance (Draxler and Rolph, 2015). Another potential source of uncertainty is the difficulty in discriminating the satellite aerosol signals from the surface reflectance using MSG-SEVIRI observations, especially over bright surfaces (Kutuzov et al., 2013). Moreover, even if the origin of the air masses was checked at the beginning, middle and end of each SLR, a larger number of sources could potentially contribute to a given aircraft sample that covers at least $120 \mathrm{~km}$ because of the aircraft's movements during SLR sampling. 
Table 3. Parameters (geometric median diameter $D_{\mathrm{p}, \mathrm{g}, i}$ in $\mu \mathrm{m}$, geometric standard deviation $\sigma_{i}$ and integrated number concentration $N_{\text {tot }}, i$ in no. $\mathrm{cm}^{-3}$ ) of the four log-normal modes $i$ used to parameterize the number size distributions obtained at the different altitudes. The mean, minimum and maximum of all parameters are listed.

\begin{tabular}{llrrrrrrrrrrrr}
\hline & & $D_{\mathrm{p}, \mathrm{g}, 1}$ & $\sigma_{1}$ & $N_{\text {tot, } 1}$ & $D_{\mathrm{p}, \mathrm{g}, 2}$ & $\sigma_{2}$ & $N_{\text {tot }, 2}$ & $D_{\mathrm{p}, \mathrm{g}, 3}$ & $\sigma_{3}$ & $N_{\text {tot, } 3}$ & $D_{\mathrm{p}, \mathrm{g}, 4}$ & $\sigma_{4}$ & $N_{\text {tot, } 4}$ \\
\hline Above-3 km & mean & 0.08 & 1.25 & 170 & 0.12 & 1.60 & 300 & 0.32 & 1.70 & 15 & 1.3 & 2.2 & 3.0 \\
dust layer & $\min$ & 0.09 & 1.20 & 80.0 & 0.13 & 1.30 & 80.0 & 0.18 & 1.65 & 40 & 2.5 & 1.8 & 0.1 \\
& $\max$ & 0.08 & 1.25 & 320 & 0.12 & 1.56 & 600 & 0.32 & 1.70 & 45 & 1.3 & 2.2 & 12 \\
\hline Below-3 km & $\operatorname{mean}$ & 0.08 & 1.25 & 300 & 0.12 & 1.60 & 700 & 0.32 & 1.70 & 15 & 2.0 & 2.4 & 1.0 \\
dust layer & $\min$ & 0.08 & 1.25 & 250 & 0.11 & 1.50 & 400 & 0.20 & 1.70 & 35 & 1.7 & 2.1 & 0.7 \\
& $\max$ & 0.08 & 1.25 & 600 & 0.13 & 1.50 & 1100 & 0.18 & 1.90 & 80 & 1.7 & 2.0 & 2.5 \\
\hline Boundary & mean & 0.08 & 1.25 & 450 & 0.12 & 1.60 & 650 & 0.32 & 1.70 & 5.0 & 1.3 & 2.1 & 1.0 \\
layer & $\min$ & 0.08 & 1.25 & 150 & 0.12 & 1.60 & 200 & 0.30 & 1.70 & 1.8 & 1.0 & 2.1 & 0.1 \\
& $\max$ & 0.08 & 1.25 & 600 & 0.12 & 1.60 & 1400 & 0.32 & 1.70 & 15 & 1.3 & 2.1 & 3.0 \\
\hline
\end{tabular}

The vertical distribution of intensive optical properties relevant to radiative transfer (i.e. single scattering albedo $\omega_{0}$, asymmetry parameter $g$ and extinction mass efficiency $k_{\text {ext }}$ ) are shown in Fig. 8c-e and Table 4. Estimates of $\omega_{0}, g$ and $k_{\text {ext }}$ fall within the range $0.90-1.00,0.6-0.8$ and $0.2-$ $0.7 \mathrm{~m}^{2} \mathrm{~g}^{-1}$ respectively. Overall, there is no clear dependence on the altitude. Only slightly low values of $g$ (from $\sim 0.7$ to $\sim 0.8$ ) and $k_{\text {ext }}$ (from $\sim 0.2$ to $\sim 0.7 \mathrm{~m}^{2} \mathrm{~g}^{-1}$ ) were observed for some dust layers below $3 \mathrm{~km}$ a.s.l. As $\tilde{n}$ was found to be constant with the altitude (i.e. Fig. 8a-b), these variations in $g$ and $k_{\text {ext }}$ were probably due to the variability in particles size distributions, which is consistent with the larger fraction of fine particles found in the below- $3 \mathrm{~km}$ dust layers (i.e. Fig. 7a). Values of $\omega_{0}, g$ and $k_{\text {ext }}$ remained, however, within the range of values reported in source regions by Schladitz et al. (2009), Formenti et al. (2011a) and Ryder et al. (2013b). Despite the fact that dust plumes carried pollution particles during their long-range transport in the Mediterranean region, the dust optical properties appeared to be unaffected by this mixing.

In the Mediterranean region, previous estimates of $\omega_{0}$ for dust particles were obtained from remote-sensing techniques. Mallet et al. (2013) reported from multi-year ground-based AERONET observations a column-averaged $\omega_{0}$ of $0.92-$ 0.95 between 440 and $880 \mathrm{~nm}$ for various sites over the Mediterranean under the influence of dust aerosols. Using a similar approach, Di Biagio et al. (2009) reported lower column-averaged $\omega_{0}$ values during dust transport events when boundary-layer air masses are transported from central Europe, probably rich in absorbing particles from urban/industrial European areas. Values as low as 0.88 at $530 \mathrm{~nm}$ were also determined by Sicard et al. (2012) during a case study of a dust plume transported over Barcelona and accompanied by a biomass-burning outbreak. Recently, Valenzuela et al. (2014) presented 8 months of dust optical properties over the Alborán Island from sun photometer measurements for dust plumes originating from northwestern Africa and passing over several urban/industrial areas along the coast of Morocco and from northeastern Africa and travelling over the Mediterranean Sea. No significant changes in column-averaged $\omega_{0}$ were reported for the different air masses, which indicates that the influence of anthropogenic fine particles originating from the urban/industrial areas in the north of Africa during desert dust outbreaks was negligible. Overall, these contrasting results highlight the major role of the transport conditions (height, air mass encountered) of the dust plumes in governing the mixing processes of mineral dust with other aerosol species.

\section{Discussion}

\subsection{On the role of transport conditions in the mixing of pollution particles with mineral dust}

In this section, we investigate the transport conditions of the dust layers expected to influence the mixing of mineral dust with pollution particles. As previously mentioned, the highest concentrations of pollution particles were detected in the below-3 km dust layers. We further investigate this result by examining the variations of $D_{\text {eff,f }}$ and $D_{\text {eff,c }}$ with the altitude of the dust plumes. We assume that changes in $D_{\text {eff,f }}$ reflected different fractions of externally mixed pollution particles smaller than $300 \mathrm{~nm}$ in the dust plumes, as discussed in Sect. 3.3. In Fig. 9a, a sharp transition in the proportion of fine particles can be seen in $D_{\text {eff,f }}$ at $3 \mathrm{~km}$ a.s.l. with a greater proportion of pollution particles found in the lower $3 \mathrm{~km}$ of the atmosphere. The observation of pollution particles at altitudes up to $3 \mathrm{~km}$ during ADRIMED is compatible with the average height of pollution layers observed in the western Mediterranean basin (Meloni et al., 2003; Mallet et al., 2005; Junkermann et al., 2009; Di Biagio et al., 2015). Hence, the vertical extent of pollution particles might explain the fact that the below- $3 \mathrm{~km}$ dust plumes were more affected by fine particles than the above- $3 \mathrm{~km}$ dust layer. The coarse mode of the dust plume is also expected to be 


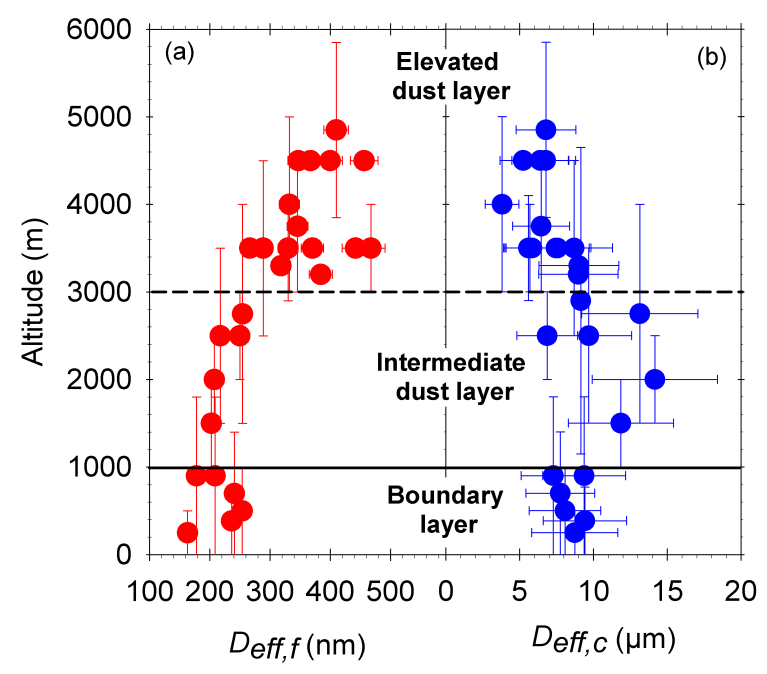

Figure 9. Altitude dependence of (a) the fine mode effective diameter $D_{\text {eff,f }}$ (size range $0.053-1 \mu \mathrm{m}$ ) and (b) the coarse mode effective diameter $D_{\text {eff,c }}$ (size range 1-20 $\mu \mathrm{m}$ ). The altitude reported for vertical profiles refers to the middle of the layer. Broad classifications of the above- $3 \mathrm{~km}$ dust layer, the below- $3 \mathrm{~km}$ dust layer and the boundary layer have been added to the figure.

Table 4. Aerosol optical parameters (real part of the complex refractive index $n_{\mathrm{r}}$, imaginary part of the complex refractive index $n_{\mathrm{i}}$, single scattering albedo $\omega_{0}$, asymmetry parameter $g$ and mass extinction efficiency $k_{\text {ext }}$ ) all at $\lambda=530 \mathrm{~nm}$ as a function of the altitude. The mean, minimum and maximum of all parameters are listed.

\begin{tabular}{llrrrrr}
\hline & & $n_{\mathrm{r}}$ & $n_{\mathrm{i}}$ & $\omega_{0}$ & $g$ & $k_{\text {ext }}$ \\
\hline Above-3 km dust layer & mean & 1.53 & 0.003 & 0.95 & 0.8 & 0.4 \\
& $\min$ & 1.50 & 0.000 & 0.90 & 0.7 & 0.3 \\
& $\max$ & 1.55 & 0.005 & 1.00 & 0.8 & 0.5 \\
\hline \multirow{2}{*}{ Below-3 km dust layer } & mean & 1.52 & 0.003 & 0.94 & 0.7 & 0.5 \\
& $\min$ & 1.50 & 0.000 & 0.90 & 0.6 & 0.4 \\
& $\max$ & 1.55 & 0.005 & 1.00 & 0.7 & 0.7 \\
\hline
\end{tabular}

impacted by the presence of pollution particles in case of an internal mixing between pollution particles and mineral dust, which should somewhat increase the mean particle size. During ADRIMED, $D_{\text {eff,c }}$ of the dust plume did not show any systematic dependence on altitude (Fig. 9b). This finding must, however, be interpreted with some caution since $D_{\text {eff,c }}$ was affected by the large uncertainties in FSSP-300 and GRIMM sizing (i.e. Sect. 2.2.1.) that might hide the detection of the effect on particle size of an aggregation of small pollution articles onto mineral dust particles.

The mixing extent of pollution particles in dust layers is also expected to depend on the transport time of the plumes.

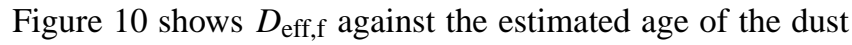
air mass and divided according to the height of transport of the dust plumes. From these measurements, we do not find any significant trend in the dust mixing rate with transport

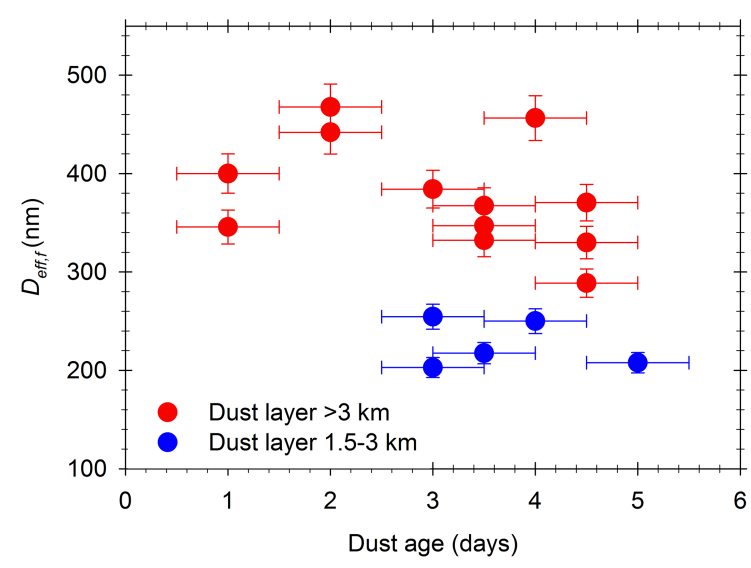

Figure 10. Effective diameter of the fine mode $D_{\text {eff,f }}$ as a function of the dust age observed for the above- $3 \mathrm{~km}$ dust layers (red circles) and the below- $3 \mathrm{~km}$ dust layers (blue circles).

time in both below- and above- $3 \mathrm{~km}$ layers. This result is not surprising for the above- $3 \mathrm{~km}$ dust layers since we found that the interaction of dust plumes with pollution particles was limited when they were transported above $3 \mathrm{~km}$ a.s.l. For dust plumes below $3 \mathrm{~km}$ a.s.l., their transport time was at least 3 days before sampling during ADRIMED. Afterwards the time spent by dust over pollution regions appeared to have no more effect on the mixing extent of pollution particles. The constant $D_{\text {eff,f }}$ values observed within the below- $3 \mathrm{~km}$ dust plumes and the boundary layer (Fig. 9a) suggests also that the vertical transport and mixing of pollution particles within dust plumes were already completed at the time of sampling. Note that the below- $3 \mathrm{~km}$ dust layers reached the Mediterranean coasts affected by urban/industrial emissions after having undergone around 2 days of transport. Hence, the pollution mixing rate appears to be a relatively rapid process more likely driven by the height of transport of the dust layers.

\subsection{Contribution of pollution particles to the absorption properties of the dust plumes}

We evaluated the effect of the contribution of pollution particles to the absorption properties of the dust layers by calculating $\omega_{0}$ from the mass concentration of the main anthropogenic compounds. Table 5 shows the mass concentration of major elements, ionic species and $\mathrm{rBC}$ measured in the dust plumes. The dust mass concentration estimated from the measured $\mathrm{Al}$ using the mean $\mathrm{Al}$ mass fraction in the crustal composition of $7.09 \%$ (Guieu et al., 2002) is also shown. In all samples, silicates were the most abundant type of dust particles, as expected from previous chemical analysis of dust in North Africa (Scheuvens et al., 2013; Formenti et al., 2014). The presence of pollution particles within the dust plumes is confirmed by the detection of $\mathrm{SO}_{4}^{2-}$ and $\mathrm{rBC}$ as well as typical anthropogenic trace elements such as $\mathrm{V}, \mathrm{Pb}$ and $\mathrm{Zn}$. 
Table 5. Concentrations of major crustal ( $\mathrm{Si}, \mathrm{Al}, \mathrm{Fe}$ and $\mathrm{Ca}$, in $\left.\mathrm{ng} \mathrm{m}^{-3}\right)$ and metallic tracers $\left(\mathrm{V}, \mathrm{Pb}\right.$ and $\mathrm{Zn}$, in $\left.\mathrm{ng} \mathrm{m}^{-3}\right)$, ionic species $\left(\mathrm{SO}_{4}^{2-}\right.$, $\mathrm{NO}_{3}^{2-}, \mathrm{NH}_{4}^{+}$, in $\mathrm{ng} \mathrm{m}^{-3}$ ), black carbon (in $\mathrm{ng} \mathrm{m}^{-3}$ ), mineral dust (in $\mu \mathrm{g} \mathrm{m}^{-3}$ ) and integrated fine mode of particles (in no. $\mathrm{cm}^{-3}$ ) during the ChArMEx/ADRIMED airborne campaign. Dash indicates that the species concentration was lower than the detection limit. The dust mass concentration was estimated from the measured Al using the mean Al mass fraction in the crustal composition of $7.09 \%$ (Guieu et al., 2002). A comparison of the aerosol single scattering albedos $\omega_{0}$ measured by the nephelometer and CAPS with those estimated from chemical measurements is also shown. The absolute error associated with $\omega_{0}$ obtained from measurements is 0.04 .

\begin{tabular}{lrrrrrrrrr}
\hline Flight number & F29 & F30 & F31 & F32 & F33 & F34 & F35 & F38 & F42 \\
\hline $\mathrm{Si}$ & 3607 & 4955 & 4159 & 592 & 2426 & 9814 & 6430 & 2040 & 5366 \\
$\mathrm{Al}$ & 1404 & 2028 & 1719 & 225 & 975 & 3770 & 2519 & 746 & 2146 \\
$\mathrm{Fe}$ & 687 & 1085 & 845 & 146 & 536 & 1869 & 1239 & 416 & 1032 \\
$\mathrm{Ca}$ & 1099 & 1596 & 1547 & - & 1322 & 6404 & 2112 & 1374 & 1592 \\
$\mathrm{~V}$ & 9 & 6 & 5 & 17 & 16 & 22 & 19 & 13 & - \\
$\mathrm{Pb}$ & 82 & 458 & 28 & 216 & 417 & - & 762 & - & - \\
$\mathrm{Zn}$ & 20 & 34 & 25 & 4 & - & - & 71 & - & - \\
$\mathrm{SO}_{4}^{2-}$ & - & 1740 & - & 2016 & 1574 & 2505 & 966 & 1764 & 2011 \\
$\mathrm{NO}_{3}^{-}$ & - & - & - & 206 & - & 285 & 309 & - & 467 \\
$\mathrm{NH}_{4}^{+}$ & - & 809 & 276 & 640 & 563 & 613 & - & 557 & - \\
$\mathrm{rBC}$ & 62 & 97 & 64 & 130 & 57 & 97 & 37 & 97 & 78 \\
$\mathrm{Dust}_{N}$ & 15.1 & 21.7 & 18.4 & 2.4 & 10.5 & 40.5 & 27.0 & 8.0 & 23.0 \\
$N_{\text {fine }}$ & 316 & 416 & 457 & 881 & 515 & 988 & 229 & 485 & 714 \\
$\omega_{0}$ (measured) & 0.97 & 1.00 & 0.99 & 0.92 & 0.98 & 0.94 & 0.97 & 0.94 & 0.99 \\
$\omega_{0}$ (chemistry) & 0.93 & 0.96 & 0.95 & 0.94 & 0.96 & 0.96 & 0.97 & 0.94 & 0.96 \\
\hline
\end{tabular}

$\mathrm{SO}_{4}^{2-}$ reached concentrations typical of the Mediterranean region in summertime (Ripoll et al., 2015) with the largest concentration of $2.5 \mu \mathrm{g} \mathrm{m}^{-3}$ found over Corsica during the flight F34. The positive correlation between the concentration of $\mathrm{SO}_{4}^{2-}$ and $N_{\text {fine }}$ indicates the presence of externally mixed sulfate-containing particles in the fine mode particles, such as ammonium sulfate particles. $\mathrm{SO}_{4}^{2-} / \mathrm{NH}_{4}^{+}$ratios being higher than unity, the presence of $\mathrm{SO}_{4}^{2-}$ in the dust layers can also either be due to nucleation of sulfuric acid in polluted plumes or to sulfate formation at the surface of preexistent particles by uptake of gaseous sulfur dioxide or by coagulation of sulfate particles (Ullerstam et al., 2002; Korhonen et al., 2003; Sullivan et al., 2009).

Concentrations of $\mathrm{rBC}$ ranged from 0.04 to $0.13 \mu \mathrm{g} \mathrm{m}^{-3}$. Although these values are much lower than concentrations measured in areas of high industrial or traffic density (Liu et al., 2014; Mantas et al., 2014), they are in agreement with concentrations found in continental and background areas of the western Mediterranean (Ripoll et al., 2015). Except in the case of large forest fires, $\mathrm{rBC}$ concentrations are generally low on average in summertime due to the absence of the major sources of emission, such as domestic wood burning (Tsyro et al., 2007).

Calculations of $\omega_{0}$ from the aerosol chemical composition were performed assuming that dust was externally mixed with $\mathrm{rBC}$ and sulfate. Indeed, prevalence of an external mixing between dust particles and $\mathrm{rBC}$ has been observed from long-term measurements in the western Mediterranean basin (Ripoll et al., 2015). Moreover, coating of sulfate on mineral dust has been shown to have no significant effect on dust optical properties (Bauer et al., 2007). Calculations of $\omega_{0}$ at $530 \mathrm{~nm}$ were performed as follows:

$\omega_{0}=\frac{\sum_{j}\left(k_{\mathrm{ext}, j}-k_{\mathrm{abs}, j}\right) \cdot C_{\mathrm{m}, j}}{\sum_{j} k_{\mathrm{ext}, j} \cdot C_{\mathrm{m}, j}}$.

We used mean mass absorption and extinction efficiencies (i.e. the total light absorption or extinction per unit mass of aerosol, referred as $k_{\text {abs }}$ and $k_{\text {ext }}$ ) of 0.02 and $0.64 \mathrm{~m}^{2} \mathrm{~g}^{-1}$ for dust (Hess et al., 1998), 7.5 and $9.4 \mathrm{~m}^{2} \mathrm{~g}^{-1}$ for $\mathrm{rBC}$ (Bond and Bergstrom, 2006) and 0 and $5.0 \mathrm{~m}^{2} \mathrm{~g}^{-1}$ for sulfate (Charlson et al., 1992). As shown in Table 5, $\omega_{0}$ obtained from this calculation ranged from 0.93 to 0.97 , which falls within the range of values obtained from measurements (0.92-0.99). For comparison, we estimate that $\omega_{0}$ for pure mineral dust was 0.97 . This simple approach confirms the small influence of pollution particles on the optical properties of the dust plumes over the western Mediterranean region.

The ChArMEx/ADRIMED field campaign was characterized by moderate AOD with averaged values ranging between 0.1 and 0.6 at $440 \mathrm{~nm}$ as observed by AERONET/PHOTONS sun photometers (see Fig. 19 of Mallet et al., 2015). Outside of dust events, the AOD displayed values from 0.1 to $0.2(440 \mathrm{~nm})$, while it reached values up to 0.8 under dusty conditions. Although higher AOD values have already been observed in the Mediterranean region during intense pollution or biomass-burning events (Pace et al., 2005; Alados-Arbodelas et al., 2011), values obtained during ADRIMED are typical of those observed in summertime (Nabat et al., 2015). This observation is also supported by the mass concentration of the main anthropogenic compounds 


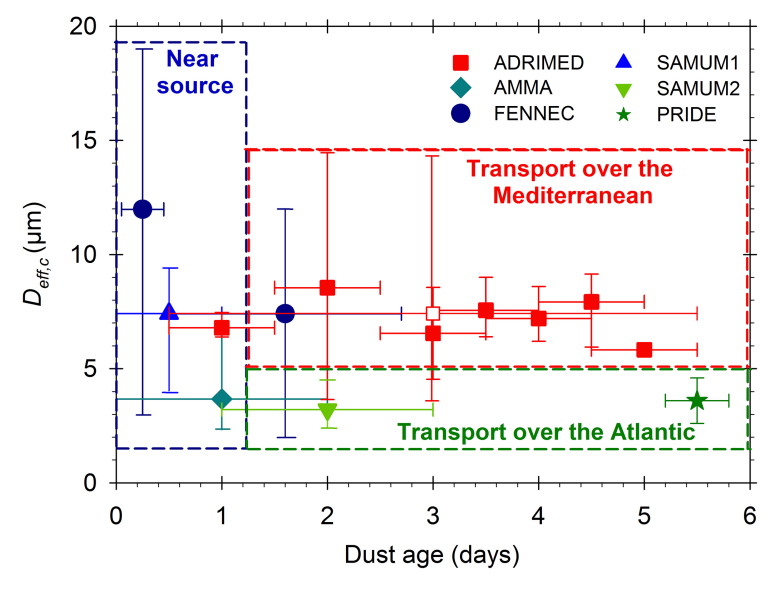

Figure 11. Effective diameter of the coarse mode $D_{\text {eff,c }}$ as a function of the dust age observed during ADRIMED (squares). Filled red squares represent the average values observed for each dust age and the empty red square represents the campaign average value. Values are compared to those observed in dust source region (in blue) during FENNEC (circles), SAMUM1 (triangle) and AMMA (diamond), as well as measurements in the Atlantic Ocean (in green) in the Cape Verde region during SAMUM-2 (triangle) and in Puerto Rico during PRIDE (stars). The horizontal error bars represent \pm 0.5 -day uncertainties on the dust age estimated using HYSPLIT and SEVIRI RGB images. The vertical error bars represent the range of values obtained for each dust age.

that reached typical values for the region, as discussed previously. Our result on the moderate absorption properties of the dust plumes is thus likely relevant to dust events in the western Mediterranean in the absence of intense pollution or biomass-burning emissions and can be used for constraining modelling studies and satellite retrievals that make assumption on dust optical properties.

We compared our measurements on dust absorption properties with values published in the OPAC aerosol database that is widely used by modelling and remote-sensing communities. The result of this comparison indicates an overestimation of dust absorption properties in the OPAC database. The $n_{\mathrm{i}}$ value achieved in the OPAC database $\left(n_{\mathrm{i}}=0.006-\right.$ 0.008 at $550-500 \mathrm{~nm}$ respectively) are high compared to values observed for Saharan mineral dust in source region and over the Mediterranean during ADRIMED $\left(n_{\mathrm{i}}\right.$ between 0.000 and 0.005 at $530 \mathrm{~nm}$ ). This finding is in line with previous studies showing disagreements in dust absorption between satellite retrievals and modelling studies that has been solved by decreasing the imaginary part of the dust refractive index (Kaufman et al., 2001; Moulin et al., 2001; Balkanski et al., 2007; Mian Chin et al., 2009).

\subsection{Retention of coarse mode particles in the dust plumes}

Figure 11 shows $D_{\text {eff,c }}$ against the estimated age of the dust air mass. Observations from aircraft during previous campaigns are shown for comparison. The $D_{\text {eff,c }}$ values did not change with time, suggesting that the dust layers transported over the Mediterranean region tend to conserve their coarse mode with time. During ADRIMED, $D_{\text {eff,c }}$ values obtained in dust layers that spent less than 1.5 days in the atmosphere are consistent with those obtained near dust source regions (Formenti et al., 2011b; Weinzierl et al., 2011). Conversely, dust layers having spent more than 1.5 days in the atmosphere present higher $D_{\text {eff,c }}$ than previously observed over the Atlantic ocean (Maring et al., 2003; Weinzierl et al., 2011). The loss of large dust particles with transport as observed over the Atlantic Ocean is most likely associated with the removal processes occurring as the dust travels downwind (Mahowald et al., 2014). As smaller particles fall downward much slower than larger particles, coarse particles are expected to be more prevalent close to the sources regions. To date only a few studies have focused on understanding the evolution of dust size distribution, especially during transport over the Atlantic Ocean (Maring et al., 2003; Reid et al., 2003; Kalashnikova and Kahn, 2008). These measurements pointed out large differences between the observed and modelled evolution of dust size, with a lifetime of coarse particles longer than expected from deposition theories. This suggests that other processes counterbalanced the loss of large particles by dry deposition along transport. These processes seem to be particularly important in the Mediterranean region, since the proportional volume of coarse particles in the size distribution did not vary substantially even after 5 days of transport.

The persistence of coarse particles over the Mediterranean basin during transport could be explained by the presence of temperature inversions in the middle troposphere keeping the dust layers confined due to the stable stratification. This was revealed by most of the aircraft temperature profiles (Fig. S7). Furthermore, the WRF model simulations of the vertical velocity and vertical cross-section confirms previous indications (Dulac et al., 1992) of the existence of up$\mathrm{draft} /$ downdraft due to the thermal turbulence within the dust layers circulating over the Mediterranean basin in summertime, due to elevated temperatures within the dust layers and large insolation. An example for flight F33 in the Corsica region is shown in Fig. 12, where the vertical velocity showed updrafts and downdrafts up to $0.5 \mathrm{~Pa} \mathrm{~s}^{-1}$, corresponding to about $5 \mathrm{~cm} \mathrm{~s}^{-1}$. This value is at least 1 order of magnitude greater than the gravitational settling velocity $\left(0.25 \mathrm{~cm} \mathrm{~s}^{-1}\right)$ expected for particles of $8 \mu \mathrm{m}$ in diameter, the value indicated by Maring et al. (2003) as the threshold above which sensible changes in dust size distribution during atmospheric transport across the Atlantic could be observed. The occurrence of turbulent updraft and downdraft motion could there- 

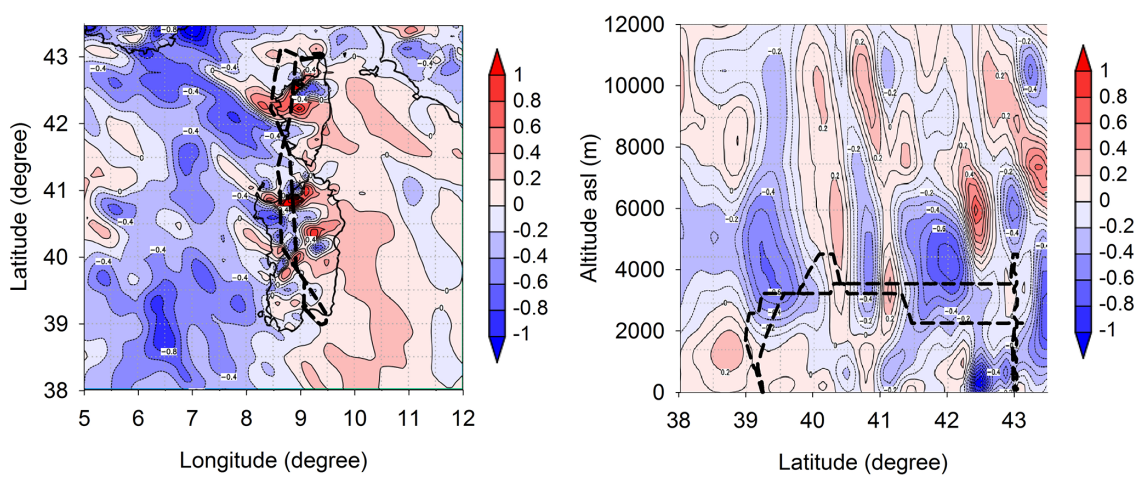

Figure 12. Wind vertical velocity (in $\mathrm{Pa} \mathrm{s}^{-1}$ ) at $700 \mathrm{hPa}$ (a) and on the vertical along the F33 flight latitude (b), from the $10 \mathrm{~km}$ resolution WRF model simulations. The dashed line shows the flight track.

fore result in an enhancement of the particle lifetime in the atmosphere over the Mediterranean basin.

\section{Conclusions}

We presented the first in situ aircraft measurements of the size distribution and optical properties of Saharan dust transported over the western Mediterranean basin obtained within the framework of the ChArMEx/ADRIMED airborne campaign in June-July 2013. Dust particles originating from Algeria, Tunisia and Morocco were sampled in the western Mediterranean basin after 1 to 5 days of transport from the source regions.

Measurements of aerosol vertical profiles revealed that dust particles were transported inside well-defined layers above the boundary layer ( $>1 \mathrm{~km}$ a.s.l.), itself dominated by pollution and marine particles. The dust vertical structure was extremely variable and characterized either by a single layer or a more complex and stratified structure. Backward trajectories indicated that the multilayering of the Saharan dust corresponded to air masses originating from different dust source regions. The abundance of sub- $300 \mathrm{~nm}$ particles in the Saharan dust layers suggested a strong mixing of dust with pollution particles. The height of transport of the dust layers appeared to be the main factor affecting the mixing extent of pollution particles with mineral dust. Measurements showed higher concentrations of pollution particles in dust layers below $3 \mathrm{~km}$ a.s.l. than at higher altitude, resulting in $\AA$ up to 2.2 below $3 \mathrm{~km}$ a.s.l. This coincides with the typical height of pollution layers $(\sim 3 \mathrm{~km}$ a.s.l. $)$ observed in the western Mediterranean basin.

The optical properties of the dust layers were not significantly affected by this mixing with respect to values reported for native dust. Mineral dust aerosols were found to be moderately absorbing with values of $\omega_{0}$ between 0.90 and 1.00 at $530 \mathrm{~nm}$. Concurrent optical calculations from the aerosol chemical composition revealed that the contribution of pollution particles to absorption properties of the dust plumes was negligible. This was most likely due to the low contribution of $\mathrm{rBC}(\sim 2 \%$ in mass) in regards to the fraction of dust $(\sim 84 \%)$ and sulfate $(\sim 14 \%)$ in the dust plumes. The concentrations of anthropogenic particles being typical of those observed in the Mediterranean region in summertime, these results demonstrate that outside a severe episode of pollution or biomass burning, mineral dust dominate the optical properties of the dust plumes in the Mediterranean even in the presence of pollution particles.

An important question for the dust direct, semi-direct and indirect radiative effects is how long the coarse mode of dust particles is conserved during transport. We showed that the coarse mode was conserved even after 5 days of transport in the Mediterranean, which contrasts with the gravitational depletion of large dust particles observed during the transport of dust over the Atlantic Ocean. The global importance of this result is, however, still linked to whether these observations are ubiquitous or occur only for specific dust transport events. Dust events differing in terms of source region, time and height for transport were reported in this study. For all these case studies, the coarse mode of dust particles was conserved during transport, which might reflect the representativeness of the situation mostly occurring in summertime in the western Mediterranean basin.

Most climate models currently simulate the dry deposition as a positive relationship of the particles size, leading in an underestimation of the fraction of coarse particles being transported long distances (Mahowald et al., 2014). Given the scarcity of field studies investigating the evolution of the dust size distribution during transport, our results point out key processes controlling the retention of large dust aerosols particles. In particular, WRF model simulations highlighted a strong turbulence within the dust layer with vertical velocity at least 1 order of magnitude greater than the particle gravitational settling velocity. Particles could therefore remain trapped in the atmosphere by this strong turbulence. Further studies involving a deep analysis of aircraft measurements of turbulence parameters both in the Mediterranean and in other geographical areas such as the Atlantic region are required in 
order to quantitatively characterize this process and improve the representativeness of the temporal evolution of dust size distribution in climate models useful for radiative impact or marine biogeochemical applications.

The data set obtained during the ChArMEx/ADRIMED airborne campaign can also be used for constraining satellite retrievals that make assumptions on dust properties in order to derive water vapour profiles, surface temperatures and greenhouse gas concentrations. The results presented here suggest that the aerosol particle size and optical properties of the dust plumes could be assimilated to those of native dust in satellite retrievals in the western Mediterranean. A straightforward comparison of our results with values published in the OPAC aerosol database, which is widely used by the remote-sensing communities, suggests that the OPAC database overestimates dust absorption. Moreover, this important data set provides opportunities for evaluating satellite aerosol products (size, absorption properties, vertical profiles) over the Mediterranean through comparison with our in situ airborne measurements.

In terms of significance for direct and semi-direct radiative effects, the presence of moderately absorbing particles within the dust layers can induce important modifications in the tropospheric heating and surface cooling by perturbing the incoming and outgoing radiations. Evidence for retention of coarse mode particles in the dust layers indicates also that mineral dust may still be a significant source of cloud condensation nuclei and ice nuclei despite having undergone long-range transport. Hence, mineral dust may have potentially important implications for the regional climate and the rainfall patterns in the western Mediterranean that should be quantitatively addressed in future modelling studies.

\section{The Supplement related to this article is available online at doi:10.5194/acp-16-1081-2016-supplement.}

Acknowledgements. This research work has been supported by the French National Research Agency (ANR) through the ADRIMED program (contract ANR-11-BS56-0006). This work is part of the ChArMEx project supported by CNRS-INSU, ADEME, MétéoFrance and CEA in the framework of the multidisciplinary program MISTRALS (Mediterranean Integrated Studies aT Regional And Local Scales; http://mistrals-home.org/). The aircraft deployment was also supported by CNES. We thank the instrument scientists, pilots and ground crew of SAFIRE for facilitating the instrument integration and conducting flight operations. We acknowledge Pierre Nabat and the ENM students, especially Damien Serça, Jonathan Guth and Valentin Seigner for their meteorological forecasts during the campaign. We thank the NOAA Air Resources Laboratory (ARL) for the provision of the HYSPLIT transport and dispersion model used in this study. We gratefully acknowledge the two anonymous reviewers and the editor whose suggestions helped us improve and clarify this manuscript.
Edited by: F. Dulac

\section{References}

Alados-Arboledas, L., Müller, D., Guerroro-Rascado, J. L., NavasGuzman, D., Pérez-Ramirez, D., and Olmo, F. J.: Optical and microphysical properties of fresh biomass burning aerosol retrieved by Raman lidar, and star-and sun-photometry, Geophys. Res. Lett., 38, L01807, doi:10.1029/2010GL45999, 2011.

Andreae, M. O. and Rosenfeld, D.: Aerosol-cloudprecipitation interactions. Part 1 . The nature and sources of cloud-active aerosols, Earth-Sci. Rev., 89, 13-41, doi:10.1016/j.earscirev.2008.03.001, 2008.

Ansmann, A., Baars, H., Tesche, M., Müller, D., Althausen, D., Engelmann, R., Pauliquevis, T., and Artaxo, P.: Dust and smoke transport from Africa to South America: Lidar profiling over Cape Verde and the Amazon rainforest, Geophys. Res. Lett., 36, L11802, doi:10.1029/2009GL037923, 2009.

Balkanski, Y., Schulz, M., Claquin, T., and Guibert, S.: Reevaluation of Mineral aerosol radiative forcings suggests a better agreement with satellite and AERONET data, Atmos. Chem. Phys., 7, 81-95, doi:10.5194/acp-7-81-2007, 2007.

Basart, S., Pérez, C., Cuevas, E., Baldasano, J. M., and Gobbi, G. P.: Aerosol characterization in Northern Africa, Northeastern Atlantic, Mediterranean Basin and Middle East from direct-sun AERONET observations, Atmos. Chem. Phys., 9, 8265-8282, doi:10.5194/acp-9-8265-2009, 2009.

Bauer, S. E., Balkanski, Y., Shulz, M., Hauglustaine, D. A., and Dentener, F., Global modelling of heterogeneous chemistry on mineral aerosol surfaces: The influence of ozone chemistry and comparison to observations, J. Geophys. Res., 109, D02304, doi:10.1029/2003JD003868, 2004.

Bauer, S. E., Mishchenko, M. I., Lacis, A. A., Zhang, S., Perlwitz, J., and Metzger, S. M.: Do sulphate and nitrate coatings on mineral dust have important effects on radiative properties and climate modeling?, J. Geophys. Res., 112, D06307, doi:10.1029/2005JD006977, 2007.

Baumgardner, D., Dye, J. E., Gandrud, B. W., and Knollenberg, R. G.: Interpretation of measurements made by forward scattering probe (FSSP-300) during the airborne arctic stratospheric expedition, J. Geophys. Res., 97, 8035-8046, doi:10.1029/91JD02728, 1992.

Baumgardner, D., Popovicheva, O., Allan, J., Bernardoni, V., Cao, J., Cavalli, F., Cozic, J., Diapouli, E., Eleftheriadis, K., Genberg, P. J., Gonzalez, C., Gysel, M., John, A., Kirchstetter, T. W., Kuhlbusch, T. A. J., Laborde, M., Lack, D., Müller, T., Niessner, R., Petzold, A., Piazzalunga, A., Putaud, J. P., Schwarz, J., Sheridan, P., Subramanian, R., Swietlicki, E., Valli, G., Vecchi, R., and Viana, M.: Soot reference materials for instrument calibration and intercomparisons: a workshop summary with recommendations, Atmos. Meas. Tech., 5, 1869-1887, doi:10.5194/amt-51869-2012, 2012.

Birmili, W., Heinke, K., Pitz, M., Matschullat, J., Wiedensohler, A., Cyrys, J., Wichmann, H.-E., and Peters, A.: Particle number size distributions in urban air before and after volatilisation, Atmos. Chem. Phys., 10, 4643-4660, doi:10.5194/acp-10-46432010, 2010. 
Bohren, C. F. and Huffman, D. R.: Absorption and scattering of light by small particles, Wiley, New York, 1983.

Bond, T. C. and Bergstrom, R. W.: Light absorption by carbonaceous particles: An investigative review, Aerosol Sci. Technol., 41, 27-47, 2006.

Bove, M. C., Brotto, P., Cassola, F., Cuccia, E., Massabò, D., Mazzino, A., Piazzalunga, A., and Prati, P.: An integrated $\mathrm{PM}_{2.5}$ source apportionment study: Positive Matrix Factorization vs. the Chemical Transport Model CAMx, Atmos. Environ., 94, 274 286, doi:10.1016/j.atmosenv.2014.05.039, 2014

Cai, Y., Montague, D. C., Mooiweer-Bryan, W., and Deshler, T.: Performance characteristics of the ultra high sensitivity aerosol spectrometer for particles between 55 and $800 \mathrm{~nm}$ : Laboratory and field studies, J. Aerosol Sci., 39, 759-769, doi:10.1016/j.jaerosci.2008.04.007, 2008.

Cassola, F., Ferrari, F., and Mazzino, A.: Numerical simulations of Mediterranean heavy precipitation events with the WRF model: A verification exercise using different approaches, Atmos. Res., 164-165, 210-225, doi:10.1016/j.atmosres.2015.05.010, 2015.

Charlson, R. J., Schwartz, S. E., Hales, J. M., Cess, R. D., Coakley, J. A., Hansen, J. E., and Hofmann, D. J.: Climate forcing by anthropogenic aerosols, Science, 255, 423-430, doi:10.1126/science.255.5043.423, 1992.

Choobari, O. A., Zawar-Reza, P., and Sturman, A.: The global distribution of mineral dust and its impacts on the climate system: A review, Atmos. Res., 138, 152-165, doi:10.1016/j.atmosres.2013.11.007, 2014.

Clarke, A. D., Shinozuka, Y., Kapustin, V. N., Howell, S., Huebert, B., Doherty, S., Anderson, T., Covert, D., Anderson, J., Hua, X., Moore, K. G., McNaughton, C., Carmichael, G., and Weber, R.: Size distributions and mixtures of dust and black carbon aerosol in Asian outflow: Physiochemistry and optical properties, J. Geophys. Res., 109, D15S09, doi:10.1029/2003JD004378, 2004.

Collaud Coen, M., Weingartner, E., Schaub, D., Hueglin, C., Corrigan, C., Henning, S., Schwikowski, M., and Baltensperger, U.: Saharan dust events at the Jungfraujoch: detection by wavelength dependence of the single scattering albedo and first climatology analysis, Atmos. Chem. Phys., 4, 2465-2480, doi:10.5194/acp4-2465-2004, 2004.

Cuesta, J., Marsham, J. H., Parker, D. J., and Flamant, C.: Dynamical mechanisms controlling the vertical redistribution of dust and the thermodynamic structure of the West Saharan atmospheric boundary layer during summer, Atmos. Sci. Lett., 10, 34-42, doi:10.1002/asl.207, 2009.

d'Almeida, G. A.: A Model for Saharan Dust Transport, J. Clim. Appl. Meteor., 25, 903-916, doi:10.1175/15200450(1986)025<0903:AMFSDT>2.0.CO;2, 1986.

DeCarlo, P., Slowik, J., Worsnop, D., Davidovits, P., and Jimenez, J.: Particle Morphology and Density Characterization by Combined Mobility and Aerodynamic Diameter Measurements. Part 1: Theory, Aerosol Sci. Tech., 38, 1185-1205, doi:10.1080/027868290903907, 2004.

de Meij, A. and Lelieveld, J.: Evaluating aerosol optical properties observed by ground-based and satellite remote sensing over the Mediterranean and the Middle East in 2006, Atmos. Res., 99, 415-433, doi:10.1016/j.atmosres.2010.11.005, 2011.

Di Biagio, C., di Sarra, A., Meloni, D., Monteleone, F., Piacentino, S., and Sferlazzo, D.: Measurements of Mediterranean aerosol radiative forcing and influence of the single scattering albedo, J. Geophys. Res., 114, D06211, doi:10.1029/2008JD011037, 2009.

Di Biagio, C., Doppler, L., Gaimoz, C., Grand, N., Ancellet, G., Raut, J.-C., Beekmann, M., Borbon, A., Sartelet, K., Attié, J.-L., Ravetta, F., and Formenti, P.: Continental pollution in the western Mediterranean basin: vertical profiles of aerosol and trace gases measured over the sea during TRAQA 2012 and SAFMED 2013 , Atmos. Chem. Phys., 15, 9611-9630, doi:10.5194/acp-15-96112015, 2015.

Di Iorio, T., di Sarra, A., Sferlazzo, D. M., Cacciani, M., Meloni, D., Monteleone, F., Fuà, D., and Fiocco, G.: Seasonal evolution of the tropospheric aerosol vertical profile in the central Mediterranean and role of desert dust, J. Geophys. Res., 114, D02201, doi:10.1029/2008JD010593, 2009.

Doherty, O. M., Riemer, N., and Hameed, S.: Saharan mineral dust transport into the Caribbean: Observed atmospheric controls and trends, J. Geophys. Res., 113, D07211, doi:10.1029/2007jd009171, 2008.

Draxler, R. R. and Rolph, G. D.: HYSPLIT (HYbrid Single-Particle Lagrangian Integrated Trajectory) Model access via NOAA ARL READY Website, available at: http://ready.arl.noaa.gov/ HYSPLIT.php (last access: 14 December 2015), NOAA Air Resources Laboratory, Silver Spring, MD, 2015.

Dulac, F. and Chazette, P.: Airborne study of a multi-layer aerosol structure in the eastern Mediterranean observed with the airborne polarized lidar ALEX during a STAAARTE campaign (7 June 1997), Atmos. Chem. Phys., 3, 1817-1831, doi:10.5194/acp-31817-2003, 2003.

Dulac, F., Bergametti, G., Losno, R., Remoudaki, E., Gomes, L., Ezat, U., and Ménard, P.: Dry deposition of mineral aerosol particles in the marine atmosphere: significance of the large size fraction, in: Precipitation Scavenging and Atmosphere-Surface Exchange, edited by: Schwartz, S. E. and Slinn, W. G. N., Hemisphere, Richland, Wa, 841-854, 1992.

Engelstaedter, S., Tegen, I., and Washington, R.: North African dust emissions and transport, Earth-Sci. Rev., 79, 73-100, doi:10.1016/j.earscirev.2006.06.004, 2006.

Environmental Modeling Center: The GFS Atmospheric Model. NCEP Office Note 442. National Oceanic and Atmospheric Administration, 2003.

Fan, X.-B., Okada, K., Niimura, N., Kai, K., Arao, K., Shi, G.-Y., Qin, Y., and Mitsuta, Y.: Mineral particles collected in china and japan during the same Asian dust-storm event, Atmos. Environ., 30, 347-351, doi:10.1016/1352-2310(95)00271-Y, 1996.

Flamant, C., Chaboureau, J. P., Parker, D. J., Taylor, C. M., Cammas, J. P., Bock, O., Timouk, F., and Pelon, J.: Airborne observations of the impact of a convective system on the planetary boundary layer thermodynamics and aerosol distribution in the inter-tropical discontinuity region of the West African Monsoon, Q. J. Roy. Meteor. Soc., 133, 1175-1189, doi:10.1002/qj.97, 2007.

Formenti, P., Andreae, M. O., Lange, L., Roberts, G., Cafmeyer, J., Rajta, I., Maenhaut, W., Holben, B. N., Artaxo, P., and Lelieveld, J.: Saharan dust in Brazil and Suriname during the Large-Scale Biosphere-Atmosphere Experiment in Amazonia (LBA) - Cooperative LBA Regional Experiment (CLAIRE) in March 1998, J. Geophys. Res., 106, 14919-14934, doi:10.1029/2000JD900827, 2001. 
Formenti, P., Elbert, W., Maenhaut, W., Haywood, J., and Andreae, M. O.: Chemical composition of mineral dust aerosol during the Saharan Dust Experiment (SHADE) airborne campaign in the Cape Verde region, September 2000, J. Geophys. Res., 108, 8576, doi:10.1029/2002JD002648, 2003.

Formenti, P., Rajot, J. L., Desboeufs, K., Caquineau, S., Chevaillier, S., Nava, S., Gaudichet, A., Journet, E., Triquet, S., Alfaro, S., Chiari, M., Haywood, J., Coe, H., and Highwood, E.: Regional variability of the composition of mineral dust from western Africa: Results from the AMMA SOP0/DABEX and DODO field campaigns, J. Geophys. Res., 113, D00C13, doi:10.1029/2008JD009903, 2008.

Formenti, P., Rajot, J. L., Desboeufs, K., Saïd, F., Grand, N., Chevaillier, S., and Schmechtig, C.: Airborne observations of mineral dust over western Africa in the summer Monsoon season: spatial and vertical variability of physico-chemical and optical properties, Atmos. Chem. Phys., 11, 6387-6410, doi:10.5194/acp-11-6387-2011, 2011a.

Formenti, P., Schütz, L., Balkanski, Y., Desboeufs, K., Ebert, M., Kandler, K., Petzold, A., Scheuvens, D., Weinbruch, S., and Zhang, D.: Recent progress in understanding physical and chemical properties of African and Asian mineral dust, Atmos. Chem. Phys., 11, 8231-8256, doi:10.5194/acp-11-8231-2011, 2011 b.

Formenti, P., Caquineau, S., Desboeufs, K., Klaver, A., Chevaillier, S., Journet, E., and Rajot, J. L.: Mapping the physicochemical properties of mineral dust in western Africa: mineralogical composition, Atmos. Chem. Phys., 14, 10663-10686, doi:10.5194/acp-14-10663-2014, 2014.

Garrett, T. J., Russell, L. M., Ramaswamy, V., Maria, S. F., and Huebert, B. J.: Microphysical and radiative evolution of aerosol plumes over the tropical North Atlantic Ocean, J. Geophys. Res., 108, 4022, doi:10.1029/2002JD002228, 2003.

Ginoux, P., Prospero, J. M., Gill, T. E., Hsu, N. C., and Zhao, M.: Global-scale attribution of anthropogenic and natural dust sources and their emission rates based on MODIS Deep Blue aerosol products, Rev. Geophys., 50, RG3005, doi:10.1029/2012RG000388, 2012.

Gkikas, A., Houssos, E. E., Hatzianastassiou, N., Papadimas, C. D., and Bartzokas, A.: Synoptic conditions favouring the occurrence of aerosol episodes over the broader Mediterranean basin, Q. J. Roy. Meteor. Soc., 138, 932-949, doi:10.1002/qj.978, 2012.

Gobbi, G. P., Barnada, F., Giorgi, R., and Santacasa, A.: Altituderesolved properties of a Saharan dust event over the Mediterranean, Atmos. Environ., 34, 5119-5127, 2000.

Gomes, L., Bergametti, G., Coudé-Gaussen, G., and Rognon, P.: Submicron desert dusts: a sandblasting process, J. Geophys. Res., 95, 13927-13935, doi:10.1029/JD095iD09p13927, 1990.

Gómez-Amo, J. L., Pinti, V., Di Iorio, T., di Sarra, A., Meloni, D., Becagli, S., Bellantone, V., Cacciani, M., Fuà, D., and Perrone, M. R.: The June 2007 Saharan dust event in the central Mediterranean: Observations and radiative effects in marine, urban, and sub-urban environments, Atmos. Environ., 45, 53855393, doi:10.1016/j.atmosenv.2011.06.045, 2011.

Goudie, A. S. and Middleton, N. J.: Saharan dust storms: nature and consequences, Earth-Sci. Rev., 56, 179-204, doi:10.1016/S00128252(01)00067-8, 2001

Guerrero-Rascado, J. L., Ruiz, B., and Alados-Arboledas, L.: Multispectral Lidar characterization of the vertical structure of Saha- ran dust aerosol over southern Spain, Atmos. Environ., 42, 2668 2681, doi:10.1016/j.atmosenv.2007.12.062, 2008.

Guieu, C., Loÿe-Pilot, M. D., Ridame, C., and Thomas, C.: Chemical characterization of the Saharan dust end-member: Some biogeochemical implications for the western Mediterranean Sea, J. Geophys. Res., 107, 4258, doi:10.1029/2001JD000582, 2002.

Hamonou, E., Chazette, P., Balis, D., Dulac, F., Schneider, X., Galani, E., Ancellet, G., and Papayannis, A.: Characterization of the vertical structure of Saharan dust export to the Mediterranean basin, J. Geophys. Res., 104, 22257-22270, doi:10.1029/1999JD900257, 1999.

Haywood, J. M., Johnson, B. T., Osborne, S. R., Baran, A. J., Brooks, M., Milton, S. F., Mulcahy, J., Walters, D., Allan, R. P., Klaver, A., Formenti, P., Brindley, H. E., Christopher, S., and Gupta, P.: Motivation, rationale and key results from the GERBILS Saharan dust measurement campaign, Q. J. Roy. Meteor. Soc., 137, 1106-1116, doi:10.1002/qj.797, 2011.

Heintzenberg, J.: The SAMUM-1 experiment over Southern Morocco: overview and introduction, Tellus B, 61, 2-11, doi:10.1111/j.1600-0889.2008.00403.x, 2009.

Hess, M., Koepke, P., and Schult, I.: Optical Properties of Aerosols and Clouds: The Software Package OPAC, B. Am. Meteorol. Soc., 79, 831-844, doi:10.1175/15200477(1998)079<0831:OPOAAC>2.0.CO;2, 1998.

Hinds, W. C.: Aerosol Technology: Properties, Behavior, and Measurement of Airborne Particles, 2nd Edn., Wiley, New York, 1999.

Huneeus, N., Chevallier, F., and Boucher, O.: Estimating aerosol emissions by assimilating observed aerosol optical depth in a global aerosol model, Atmos. Chem. Phys., 12, 4585-4606, doi:10.5194/acp-12-4585-2012, 2012.

IPCC: Fifth assessment report - the physical science basis, available at: http://www.ipcc.ch (last access: 14 December 2015), 2013.

Jing, S., Jianping Huang, Qiang Fu, Minnis, P., Jinming Ge, and Jianrong Bi: Estimation of Asian dust aerosol effect on cloud radiation forcing using Fu-Liou radiative model and CERES measurements, Atmos. Chem. Phys., 8, 2763-2771, doi:10.5194/acp8-2763-2008, 2008.

Junkermann, W.: On the distribution of formaldehyde in the western Po-Valley, Italy, during FORMAT 2002/2003, Atmos. Chem. Phys., 9, 9187-9196, doi:10.5194/acp-9-9187-2009, 2009.

Kaaden, N., Massling, A., Schladitz, A., Muller, T., Kandler, K., Schutz, L., Weinzierl, B., Petzold, A., Tesche, M., Leinert, S., Deutscher, C., Ebert, M., Weinbruch, S., and Wiedensohler, A.: State of mixing, shape factor, number size distribution, and hygroscopic growth of the Saharan anthropogenic and mineral dust aerosol at Tinfou, Morocco, Tellus B, 61, 51-63, doi:10.1111/j.1600-0889.2008.00388.x, 2009.

Kalashnikova, O. V. and Kahn, R. A.: Mineral dust plume evolution over the Atlantic from MISR and MODIS aerosol retrievals, J. Geophys. Res., 113, D24204, doi:10.1029/2008JD010083, 2008.

Kalnay, E., Kanamitsu, M., Kistler, R., Collins, W., Deaven, D., Gandin, L., Iredell, M., Saha, S., White, G., Woollen, J., Zhu, Y., Leetmaa, A., Reynolds, R., Chelliah, M., Ebisuzaki, W., Higgins, W., Janowiak, J., Mo, K. C., Ropelewski, C., Wang, J., Jenne, R., and Joseph, D.: The NCEP/NCAR 40-Year Reanalysis Project, B. Am. Meteorol. Soc., 77, 437-471, doi:10.1175/15200477(1996)077<0437:TNYRP>2.0.CO;2, 1996. 
Kandler, K., Schütz, L., Deutscher, C., Ebert, M., Hofmann, H., Jäckel, S., Jaenicke, R., Knippertz, P., Lieke, K., Massling, A., Petzold, A., Schladitz, A., Weinzierl, B., Wiedensohler, A., Zorn, S., and Weinbruch, S.: Size distribution, mass concentration, chemical and mineralogical composition and derived optical parameters of the boundary layer aerosol at Tinfou, Morocco, during SAMUM 2006, Tellus B, 61, 32-50, doi:10.1111/j.16000889.2008.00385.x, 2009.

Kanitz, T., Engelmann, R., Heinold, B., Baars, H., Skupin, A., and Ansmann, A.: Tracking the Saharan Air Layer with shipborne lidar across the tropical Atlantic, Geophys. Res. Lett., 41, 10441050, doi:10.1002/2013GL058780, 2014.

Kaufman, Y. J., Tanré, D., Dubovik, D. O., Karnieli, A., and Remer, L. A.: Absorption of sunlight by dust as inferred from satellite and ground-based remote sensing, Geophys. Res. Lett., 28, 1479-1482, 2001.

Koçak, M., Theodosi, C., Zarmpas, P., Séguret, M. J. M., Herut, B., Kallos, G., Mihalopoulos, N., Kubilay, N., and Nimmo, M.: Influence of mineral dust transport on the chemical composition and physical properties of the Eastern Mediterranean aerosol, Atmos. Environ., 57, 266-277, doi:10.1016/j.atmosenv.2012.04.006, 2012.

Koehler, K. A., Kreidenweis, S. M., DeMott, P. J., Petters, M. D., Prenni, A. J., and Carrico, C. M.: Hygroscopicity and cloud droplet activation of mineral dust aerosol, Geophys. Res. Lett., 36, L08805, doi:10.1029/2009GL037348, 2009.

Koren, I., Joseph, J. H., and Israelevich, P.: Detection of dust plumes and their sources in northeastern Libya, Can. J. Remote Sens., 29, 792-796, doi:10.5589/m03-036, 2003.

Korhonen, H., Napari, I., Timmreck, C., Vehkamäki, H., Pirjola, L., Lehtinen, K. E. J., Lauri, A., and Kulmala, M.: Heterogeneous nucleation as a potential sulphate-coating mechanism of atmospheric mineral dust particles and implications of coated dust on new particle formation, J. Geophys. Res., 108, 4546, doi:10.1029/2003JD003553, 2003.

Kutuzov, S., Shahgedanova, M., Mikhalenko, V., Ginot, P., Lavrentiev, I., and Kemp, S.: High-resolution provenance of desert dust deposited on Mt. Elbrus, Caucasus in 2009-2012 using snow pit and firn core records, The Cryosphere, 7, 1481-1498, doi:10.5194/tc-7-1481-2013, 2013.

Laborde, M., Mertes, P., Zieger, P., Dommen, J., Baltensperger, U., and Gysel, M.: Sensitivity of the Single Particle Soot Photometer to different black carbon types, Atmos. Meas. Tech., 5, 10311043, doi:10.5194/amt-5-1031-2012, 2012.

Levin, Z., Ganor, E., and Gladstein, V.: The Effects of Desert Particles Coated with Sulfate on Rain Formation in the Eastern Mediterranean, J. Appl. Meteor., 35, 1511-1523, doi:10.1175/1520-0450(1996)035<1511:TEODPC>2.0.CO;2, 1996.

Levin, Z., Teller, A., Ganor, E., and Yin, Y.: On the interactions of mineral dust, sea-salt particles, and clouds: A measurement and modeling study from the Mediterranean Israeli Dust Experiment campaign, J. Geophys. Res., 110, D20202, doi:10.1029/2005JD005810, 2005.

Liu, Y. G. and Daum, P. H.: Relationship of refractive index to mass density and self-consistency of mixing rules for multicomponent mixtures like ambient aerosols, J. Aerosol Sci., 39, 974-986, doi:10.1016/j.jaerosci.2008.06.006, 2008.
Liu, D., Allan, J. D., Young, D. E., Coe, H., Beddows, D., Fleming, Z. L., Flynn, M. J., Gallagher, M. W., Harrison, R. M., Lee, J., Prevot, A. S. H., Taylor, J. W., Yin, J., Williams, P. I., and Zotter, P.: Size distribution, mixing state and source apportionment of black carbon aerosol in London during wintertime, Atmos. Chem. Phys., 14, 10061-10084, doi:10.5194/acp14-10061-2014, 2014.

Ma, Q. X., Liu, Y. C., Liu, C., and He, H.: Heterogeneous reaction of acetic acid on $\mathrm{MgO}$, alpha- $\mathrm{Al}_{2} \mathrm{O}_{3}$, and $\mathrm{CaCO}_{3}$ and the effect on the hygroscopic behaviour of these particles, Phys. Chem. Chem. Phys., 14, 8403-8409, doi:10.1039/c2cp40510e, 2012.

Mahowald, N., Albani, S., Kok, J. F., Engelstaeder, S., Scanza, R., Ward, D. S., and Flanner, M. G.: The size distribution of desert dust aerosols and its impact on the Earth system, Aeolian Research, 15, 53-71, doi:10.1016/j.aeolia.2013.09.002, 2014.

Mallet, M., Van Dingenen, R., Roger, J. C., Despiau, S., and Cachier, H.: In situ airborne measurements of aerosol optical properties during photochemical pollution events, J. Geophys. Res., 110, D03205, doi:10.1029/2004jd005139, 2005.

Mallet, M., Dubovik, O., Nabat, P., Dulac, F., Kahn, R., Sciare, J., Paronis, D., and Léon, J. F.: Absorption properties of Mediterranean aerosols obtained from multi-year ground-based remote sensing observations, Atmos. Chem. Phys., 13, 9195-9210, doi:10.5194/acp-13-9195-2013, 2013.

Mallet, M., Dulac, F., Formenti, P., Nabat, P., Sciare, J., Roberts, G., Pelon, J., Ancellet, G., Tanré, D., Parol, F., di Sarra, A., Alados, L., Arndt, J., Auriol, F., Blarel, L., Bourrianne, T., Brogniez, G., Chazette, P., Chevaillier, S., Claeys, M., D’Anna, B., Denjean, C., Derimian, Y., Desboeufs, K., Di Iorio, T., Doussin, J.-F., Durand, P., Féron, A., Freney, E., Gaimoz, C., Goloub, P., Gómez-Amo, J. L., Granados-Muñoz, M. J., Grand, N., Hamonou, E., Jankowiak, I., Jeannot, M., Léon, J.-F., Maillé, M., Mailler, S., Meloni, D., Menut, L., Momboisse, G., Nicolas, J., Podvin, J., Pont, V., Rea, G., Renard, J.-B., Roblou, L., Schepanski, K., Schwarzenboeck, A., Sellegri, K., Sicard, M., Solmon, F., Somot, S., Torres, B., Totems, J., Triquet, S., Verdier, N., Verwaerde, C., Wenger, J., and Zapf, P.: Overview of the ChemistryAerosol Mediterranean Experiment/Aerosol Direct Radiative Forcing on the Mediterranean Climate (ChArMEx/ADRIMED) summer 2013 campaign, Atmos. Chem. Phys. Discuss., 15, 19615-19727, doi:10.5194/acpd-15-19615-2015, 2015.

Mantas, E., Remoundaki, E., Halari, I., Kassomenos, P., Theodosi, C., Hatzikioseyian, A., and Mihalopoulos, N.: Mass closure and source apportionment of $\mathrm{PM}_{2.5}$ by Positive Matrix Factorization analysis in urban Mediterranean environment, Atmos. Environ., 94, 154-163, doi:10.1016/j.atmosenv.2014.05.002, 2014.

Marconi, M., Sferlazzo, D. M., Becagli, S., Bommarito, C., Calzolai, G., Chiari, M., di Sarra, A., Ghedini, C., Gómez-Amo, J. L., Lucarelli, F., Meloni, D., Monteleone, F., Nava, S., Pace, G., Piacentino, S., Rugi, F., Severi, M., Traversi, R., and Udisti, R.: Saharan dust aerosol over the central Mediterranean Sea: $\mathrm{PM}_{10}$ chemical composition and concentration versus optical columnar measurements, Atmos. Chem. Phys., 14, 2039-2054, doi:10.5194/acp-14-2039-2014, 2014.

Maring, H., Savoie, D. L., Izaguirre, M. A., Custals, L., and Reid, J. S.: Mineral dust aerosol size distribution change during atmospheric transport, J. Geophys. Res., 108, 8592, doi:10.1029/2002jd002536, 2003. 
Massoli, P., Kebabian, P. L., Onasch, T. B., Hills, F. B., and Freedman, A., Aerosol light extinction measurements by Cavity Attenuated Phase Shift (CAPS) Spectroscopy: Laboratory validation and field deployment of a compact aerosol particle extinction monitor, Aerosol Sci. Tech., 44, 428-435, doi:10.1080/02786821003716599, 2010.

McConnell, C. L., Highwood, E. J., Coe, H., Formenti, P., Anderson, B., Osborne, S., Nava, S., Desboeufs, K., Chen, G., and Harrison, M. A. J.: Seasonal variations of the physical and optical characteristics of Saharan dust: Results from the Dust Outflow and Deposition to the Ocean (DODO) experiment, J. Geophys. Res., 113, D14505, doi:10.1029/2007jd009606, 2008.

Meloni, D., di Sarra, A., DeLuisi, J., Di Iorio, T., Fiocco, G., Junkermann, W., and Pace, G.: Tropospheric aerosols in the Mediterranean: 2. Radiative effects through model simulations and measurements, J. Geophys. Res., 108, 4317, doi:10.1029/2002JD002807, 2003.

Meloni, D., di Sarra, A., Pace, G., and Monteleone, F.: Aerosol optical properties at Lampedusa (Central Mediterranean). 2. Determination of single scattering albedo at two wavelengths for different aerosol types, Atmos. Chem. Phys., 6, 715-727, doi:10.5194/acp-6-715-2006, 2006.

Mentaschi, L., Besio, G., Cassola, F., and Mazzino, A.: Performance evaluation of WavewatchIII in the Mediterranean Sea, Ocean Model., 90, 82-94, doi:10.1016/j.ocemod.2015.04.003, 2015.

Mian Chin, Diehl, T., Dubovik, O., Eck, T. F., Holben, B. N., Sinyuk, A., and Streets, D. G.: Light absorption by pollution, dust, and biomass burning aerosols: a global model study and evaluation with AERONET measurements, Ann. Geophys., 27, 3439-3464, doi:10.5194/angeo-27-3439-2009, 2009.

Mishchenko, M. I., Lacis, A. A., Carlson, B. E., and Travis, L. D.: Nonsphericity of dust-like tropospheric aerosols : implications for aerosol remote sensing and climate modelling, Geophys. Res. Lett., 22, 1077-1080, 1995.

Mona, L., Amodeo, A., Pandolfi, M., and Pappalardo, G.: Saharan dust intrusions in the Mediterranean area: Three years of Raman lidar measurements, J. Geophys. Res., 111, D16203, doi:10.1029/2005JD006569, 2006.

Moteki, N. and Kondo, Y.: Dependence of Laser-Induced Incandescence on Physical Properties of Black Carbon Aerosols: Measurements and Theoretical Interpretation, Aerosol Sci. Tech., 44, 663-675, doi:10.1080/02786826.2010.484450, 2010.

Moulin, C., Lambert, C. E., Dulac, F., and Dayan, U.: Control of atmospheric export of dust from North Africa by the North Atlantic Oscillation, Nature, 387, 691-694, 1997.

Moulin, C., Lambert, C. E., Dayan, U., Masson, V., Ramonet, M., Bousquet, P., Legrand, M., Balkanski, Y. J., Guelle, W., Marticorena, B., Bergametti, G., and Dulac, F.: Satellite climatology of African dust transport in the Mediterranean atmosphere, J. Geophys. Res., 103, 13137-13144, doi:10.1029/98JD00171, 1998.

Moulin, C., Gordon, H. R., Banzon, V. F., and Evans, R. H.: Assessment of Saharan dust absorption in the visible from Sea- WiFS imagery, J. Geophys. Res., 106, 18239-18250, doi:10.1029/2000JD900812, 2001.

Muller, T., Laborde, M., Kassell, G., and Wiedensohler, A.: Design and performance of a three-wavelength LED-based total scatter and backscatter integrating nephelometer, Atmos. Meas. Tech., 4, 1291-1303, doi:10.5194/amt-4-1291-2011, $2011 \mathrm{a}$.
Muller, T., Schladitz, A., Kandler, K., and Wiedensohler, A.: Spectral particle absorption coefficients, single scattering albedos and imaginary parts of refractive indices from ground based in situ measurements at Cape Verde Island during SAMUM-2, Tellus B, 63, 573-588, doi:10.1111/j.1600-0889.2011.00572.x, 2011b.

Nabat, P., Somot, S., Mallet, M., Michou, M., Sevault, F., Driouech, F., Meloni, D., di Sarra, A., Di Biagio, C., Formenti, P., Sicard, M., Léon, J.-F., and Bouin, M.-N.: Dust aerosol radiative effects during summer 2012 simulated with a coupled regional aerosolatmosphere-ocean model over the Mediterranean, Atmos. Chem. Phys., 15, 3303-3326, doi:10.5194/acp-15-3303-2015, 2015.

Osborne, S. R., Johnson, B. T., Haywood, J. M., Baran, A. J., Harrison, M. A. J., and McConnell, C. L.: Physical and optical properties of mineral dust aerosol during the Dust and Biomass-burning Experiment, J. Geophys. Res., 113, D00C03, doi:10.1029/2007jd009551, 2008.

Otto, S., Bierwirth, E., Weinzierl, B., Kandler, K., Esselborn, M., Tesche, M., Schladitz, A., Wendisch, M., and Trautmann, T.: Solar radiative effects of a Saharan dust plume observed during SAMUM assuming spheroidal model particles, Tellus B, 61, 270296, doi:10.1111/j.1600-0889.2008.00389.x, 2009.

Pace, G., Meloni, D., and di Sarra, A.: Forest fire aerosol over the Mediterranean basin during summer 2003, J. Geophys. Res., 110, D21202, doi:10.1029/2005JD005986, 2005.

Papayannis, A., Amiridis, V., Mona, L., Tsaknakis, G., Balis, D., Bosenberg, J., Chaikovski, A., De Tomasi, F., Grigorov, I., Mattis, I., Mitev, V., Muller, D., Nickovic, S., Perez, C., Pietruczuk, A., Pisani, G., Ravetta, F., Rizi, V., Sicard, M., Trickl, T., Wiegner, M., Gerding, M., Mamouri, R. E., D'Amico, G., and Pappalardo, G.: Systematic lidar observations of Saharan dust over Europe in the frame of EARLINET (2000-2002), J. Geophys. Res., 113, D10204, doi:10.1029/2007jd009028, 2008.

Perrone, M. R. and Bergamo, A.: Direct radiative forcing during Sahara dust intrusions at a site in the Central Mediterranean: Anthropogenic particle contribution, Atmos. Res., 101, 783-798, doi:10.1016/j.atmosres.2011.05.011, 2011.

Perry, K. D., Cahill, T. A., Eldred, R. A., Dutcher, D. D., and Gill, T. E.: Long-range transport of North African dust to the eastern United States, J. Geophys. Res., 102, 11225-11238, doi:10.1029/97JD00260, 1997.

Petzold, A., Rasp, K., Weinzierl, B., Esselborn, M., Hamburger, T., Dörnbrack, A., Kandler, K., Schütz, L., Knippertz, P., Fiebig, M., and Virkkula, A. K. I.: Saharan dust absorption and refractive index from aircraft-based observations during SAMUM 2006, Tellus B, 61, 118-130, doi:10.1111/j.1600-0889.2008.00383.x, 2009.

Pey, J., Querol, X., Alastuey, A., Forastiere, F., and Stafoggia, M.: African dust outbreaks over the Mediterranean Basin during 2001-2011: $\mathrm{PM}_{10}$ concentrations, phenomenology and trends, and its relation with synoptic and mesoscale meteorology, Atmos. Chem. Phys., 13, 1395-1410, doi:10.5194/acp-13-13952013, 2013.

Prospero, J. M., Ginoux, P., Torres, O., Nicholson, S. E., and Gill, T. E.: Environmental characterization of global sources of atmospheric soil dust identified with the nimbus 7 total ozone mapping spectrometer (TOMS) absorbing aerosol product, Rev. Geophys., 40, 1002, doi:10.1029/2000RG000095, 2002.

Querol, X., Alastuey, A., Pey, J., Cusack, M., Pérez, N., Mihalopoulos, N., Theodosi, C., Gerasopoulos, E., Kubilay, N., 
and Koçak, M.: Variability in regional background aerosols within the Mediterranean, Atmos. Chem. Phys., 9, 4575-4591, doi:10.5194/acp-9-4575-2009, 2009.

Reid, J. S., Kinney, J. E., Westphal, D. L., Holben, B. N., Welton, E. J., Tsay, S.-C., Eleuterio, D. P., Campbell, J. R., Christopher, S. A., Colarco, P. R., Jonsson, H. H., Livingston, J. M., Maring, H. B., Meier, M. L., Pilewskie, P., Prospero, J. M., Reid, E. A., Remer, L. A., Russell, P. B., Savoie, D. L., Smirnov, A., and Tanré, D.: Analysis of measurements of Saharan dust by airborne and ground-based remote sensing methods during the Puerto Rico Dust Experiment (PRIDE), J. Geophys. Res., 108, 8586, doi:10.1029/2002JD002493, 2003.

Renard, J.-B., Dulac, F., Berthet, G., Lurton, T., Vignelles, D., Jégou, F., Tonnelier, T., Thaury, C., Jeannot, M., Couté, B., Akiki, R., Verdier, N., Mallet, M., Gensdarmes, F., Charpentier, P., Mesmin, S., Duverger, V., Dupont, J. C., Elias, T., Crenn, V., Sciare, J., Giacomoni, J., Gobbi, M., Hamonou, E., Olafsson, H., Dagsson-Waldhauserova, P., Camy-Peyret, C., Mazel, C., Décamps, T., Piringer, M., Surcin, J., and Daugeron, D.: LOAC: a small aerosol optical counter/sizer for ground-based and balloon measurements of the size distribution and nature of atmospheric particles - Part 2: First results from balloon and unmanned aerial vehicle flights, Atmos. Meas. Tech. Discuss., 8, 10057-10096, doi:10.5194/amtd-8-10057-2015, 2015.

Ripoll, A., Minguillón, M. C., Pey, J., Pérez, N., Querol, X., and Alastuey, A.: Joint analysis of continental and regional background environments in the western Mediterranean: $\mathrm{PM}_{1}$ and $\mathrm{PM}_{10}$ concentrations and composition, Atmos. Chem. Phys., 15, 1129-1145, doi:10.5194/acp-15-1129-2015, 2015.

Rosenberg, P. D., Parker, D. J., Ryder, C. L., Marsham, J. H., Garcia-Carreras, L., Dorsey, J. R., Brooks, I. M., Dean, A. R., Crosier, J., McQuaid, J. B., and Washington, R.: Quantifying particle size and turbulent scale dependence of dust flux in the Sahara using aircraft measurements, J. Geophys. Res., 119, 75777598, doi:10.1002/2013JD021255, 2014.

Rosenfeld, D., Rudich, Y., and Lahav, R.: Desert dust suppressing precipitation: A possible desertification feedback loop, P. Natl. Acad. Sci. USA, 98, 5975-5980, doi:10.1073/pnas.101122798, 2001.

Ryder, C. L., Highwood, E. J., Lai, T. M., Sodemann, H., and Marsham, J. H.: Impact of atmospheric transport on the evolution of microphysical and optical properties of Saharan dust, Geophys. Res. Lett., 40, 2433-2438, doi:10.1002/grl.50482, 2013a.

Ryder, C. L., Highwood, E. J., Rosenberg, P. D., Trembath, J., Brooke, J. K., Bart, M., Dean, A., Crosier, J., Dorsey, J., Brindley, H., Banks, J., Marsham, J. H., McQuaid, J. B., Sodemann, H., and Washington, R.: Optical properties of Saharan dust aerosol and contribution from the coarse mode as measured during the Fennec 2011 aircraft campaign, Atmos. Chem. Phys., 13, 303325, doi:10.5194/acp-13-303-2013, 2013b.

Saha, A., Mallet, M., Roger, J. C., Dubuisson, P., Piazzola, J., and Despiau, S.: One year measurements of aerosol optical properties over an urban coastal site: Effect on local direct radiative forcing, Atmos. Res., 90, 195-202, doi:10.1016/j.atmosres.2008.02.003, 2008.

Saha, S., Moorthi, S., Pan, H.-L., Wu, X., Wang, J., Nadiga, S., Tripp, P., Kistler, R., Woollen, J., Behringer, D., Liu, H., Stokes, D., Grumbine, R., Gayno, G., Wang, J., Hou, Y.-T., Chuang, H.Y., Juang, H.-M. H., Sela, J., Iredell, M., Treadon, R., Kleist,
D., Van Delst, P., Keyser, D., Derber, J., Ek, M., Meng, J., Wei, H., Yang, R., Lord, S., Van Den Dool, H., Kumar, A., Wang, W., Long, C., Chelliah, M., Xue, Y., Huang, B., Schemm, J.-K., Ebisuzaki, W., Lin, R., Xie, P., Chen, M., Zhou, S., Higgins, W., Zou, C.-Z., Liu, Q., Chen, Y., Han, Y., Cucurull, L., Reynolds, R. W., Rutledge, G., and Goldberg, M.: The NCEP Climate Forecast System Reanalysis, B. Am. Meteorol. Soc., 91, 1015-1057, doi:10.1175/2010BAMS3001.1, 2010.

Saïd, F., Canut, G., Durand, P., Lohou, F., and Lothon, M.: Seasonal evolution of boundary-layer turbulence measured by aircraft during the AMMA 2006 Special Observation Period, Q. J. Roy. Meteor. Soc., 136, 47-65, doi:10.1002/qj.475, 2010.

Salvador, P., Alonso-Pérez, S., Pey, J., Artíñano, B., de Bustos, J. J., Alastuey, A., and Querol, X.: African dust outbreaks over the western Mediterranean Basin: 11-year characterization of atmospheric circulation patterns and dust source areas, Atmos. Chem. Phys., 14, 6759-6775, doi:10.5194/acp-14-6759-2014, 2014.

Scheuvens, D., Schütz, L., Kandler, K., Ebert, M., and Weinbruch, S.: Bulk composition of northern African dust and its source sediments - A compilation, Earth-Sci. Rev., 116, 170 194, doi:10.1016/j.earscirev.2012.08.005, 2013.

Schladitz, A., Muller, T., Kaaden, N., Massling, A., Kandler, K., Ebert, M., Weinbruch, S., Deutscher, C., and Wiedensohler, A.: In situ measurements of optical properties at Tinfou (Morocco) during the Saharan Mineral Dust Experiment SAMUM 2006, Tellus B, 61, 64-78, doi:10.1111/j.1600-0889.2008.00397.x, 2009.

Seinfeld, J. H. and Pandis, S. N.: Atmospheric chemistry and physics: From air pollution to climate change, 714 pp., 1998.

Sicard, M., Mallet, M., García-Vizcaíno, D., Comerón, A., Rocadenbosch, F., Dubuisson, P., and Muñoz-Porcar, C.: Intense dust and extremely fresh biomass burning outbreak in Barcelona, Spain: characterization of their optical properties and estimation of their direct radiative forcing, Environ. Res. Lett., 7, 034016, doi:10.1088/1748-9326/7/3/034016, 2012.

Sicard, M., Bertolín, S., Mallet, M., Dubuisson, P., and Comerón, A.: Estimation of mineral dust long-wave radiative forcing: sensitivity study to particle properties and application to real cases in the region of Barcelona, Atmos. Chem. Phys., 14, 9213-9231, doi:10.5194/acp-14-9213-2014, 2014.

Skamarock, W. C., Klemp, J. B., Dudhia, J., Gill, D. O., Barker, D. M., Huang, X. Z., Wang, W., and Powers, J. G.: A Description of the Advanced Research WRF Version 3. Technical report. Mesoscale and Microscale Meteorology Division, NCAR, Boulder, Colorado, 2008.

Sokolik, I. N. and Toon, O. B.: Direct radiative forcing by anthropogenic airborne mineral aerosols, Nature, 381, 681-683, doi:10.1038/381681a0, 1996.

Sullivan, A. P. and Weber, R. J.: Chemical characterization of the ambient organic aerosol soluble in water: 2. Isolation of acid, neutral, and basic fractions by modified sizeexclusion chromatography, J. Geophys. Res., 111, D05315, doi:10.1029/2005JD006485, 2006.

Sullivan, R. C. and Prather, K. A.: Investigations of the Diurnal Cycle and Mixing State of Oxalic Acid in Individual Particles in Asian Aerosol Outflow, Environ. Sci. Technol., 41, 8062-8069, doi:10.1021/es071134g, 2007.

Sullivan, R. C., Moore, M. J. K., Petters, M. D., Kreidenweis, S. M., Roberts, G. C., and Prather, K. A.: Effect of chemical mixing 
state on the hygroscopicity and cloud nucleation properties of calcium mineral dust particles, Atmos. Chem. Phys., 9, 33033316, doi:10.5194/acp-9-3303-2009, 2009.

Swap, R., Garstang, M., Greco, S., Talbot, R., and Kållberg, P.: Saharan dust in the Amazon Basin, Tellus B, 44, 133-149, doi:10.1034/j.1600-0889.1992.t01-1-00005.x, 1992.

Tegen, I. and Lacis, A. A.: Modeling of particle size distribution and its influence on the radiative properties of mineral dust aerosol, J. Geophys. Res., 101, 19237-19244, doi:10.1029/95JD03610, 1996.

Trochkine, D., Iwasaka, Y., Matsuki, A., Yamada, M., Kim, Y. S., Nagatani, T., Zhang, D., Shi, G. Y., and Shen, Z.: Mineral aerosol particles collected in Dunhuang, China, and their comparison with chemically modified particles collected over Japan, J. Geophys. Res., 108, 8642, doi:10.1029/2002JD003268, 2003.

Tsyro, S., Simpson, D., Tarrasón, L., Klimont, Z., Kupiainen, K., Pio, C., and Yttri, K. E.: Modeling of elemental carbon over Europe, J. Geophys. Res., 112, D23S19, doi:10.1029/2006JD008164, 2007.

Ullerstam, M., Vogt, R., Langer, S., and Ljungstrom, E.: The kinetics and mechanism of $\mathrm{SO}_{2}$ oxidation by $\mathrm{O}_{3}$ on mineral dust, Phys. Chem. Chem. Phys., 4, 4694-4699, doi:10.1039/B203529B, 2002.

Valenzuela, A., Olmo, F. J., Lyamani, H., Granados-Muñoz, M. J., Antón, M., Guerrero-Rascado, J. L., Quirantes, A., Toledano, C., Perez-Ramírez, D., and Alados-Arboledas, L.: Aerosol transport over the Werstern Mediterranean bassin: Evidence of fine particles to desert plumes over Alboran Island, J. Geophys. Res., 119, 14028-14044, doi:10.1002/2014JD022044, 2014.

Van Dingenen, R., Putaud, J.-P., Martins-Dos Santos, S., and Raes, F.: Physical aerosol properties and their relation to air mass origin at Monte Cimone (Italy) during the first MINATROC campaign, Atmos. Chem. Phys., 5, 2203-2226, doi:10.5194/acp-52203-2005, 2005.

Villani, P., Picard, D., Marchand, N., and Laj, P.: Design and Validation of a 6-Volatility Tandem Differential Mobility Analyzer (VTDMA), Aerosol Sci. Tech., 41, 898-906, doi:10.1080/02786820701534593, 2007.
Weinzierl, B., Petzold, A., Esselborn, M., Wirth, M., Rasp, K., Kandler, K., SchÜTz, L., Koepke, P., and Fiebig, M.: Airborne measurements of dust layer properties, particle size distribution and mixing state of Saharan dust during SAMUM 2006, Tellus B, 61, 96-117, doi:10.1111/j.1600-0889.2008.00392.x, 2009.

Weinzierl, B., Sauer, D., Esselborn, M., Petzold, A., Veira, A., Rose, M., Mund, S., Wirth, M., Ansmann, A., Tesche, M., Gross, S., and Freudenthaler, V.: Microphysical and optical properties of dust and tropical biomass burning aerosol layers in the Cape Verde region-an overview of the airborne in situ and lidar measurements during SAMUM-2, Tellus B, 63, 589-618, doi:10.1111/j.1600-0889.2011.00566.x, 2011.

Wiedensohler, A., Birmili, W., Nowak, A., Sonntag, A., Weinhold, K., Merkel, M., Wehner, B., Tuch, T., Pfeifer, S., Fiebig, M., Fjäraa, A. M., Asmi, E., Sellegri, K., Depuy, R., Venzac, H., Villani, P., Laj, P., Aalto, P., Ogren, J. A., Swietlicki, E., Williams, P., Roldin, P., Quincey, P., Hüglin, C., Fierz-Schmidhauser, R., Gysel, M., Weingartner, E., Riccobono, F., Santos, S., Grüning, C., Faloon, K., Beddows, D., Harrison, R., Monahan, C., Jennings, S. G., O’Dowd, C. D., Marinoni, A., Horn, H.-G., Keck, L., Jiang, J., Scheckman, J., McMurry, P. H., Deng, Z., Zhao, C. S., Moerman, M., Henzing, B., de Leeuw, G., Löschau, G., and Bastian, S.: Mobility particle size spectrometers: harmonization of technical standards and data structure to facilitate high quality long-term observations of atmospheric particle number size distributions, Atmos. Meas. Tech., 5, 657-685, doi:10.5194/amt5-657-2012, 2012.

Zhou, M., Okada, K., Qian, F., Wu, P. M., Su, L., Casareto, B. E., and Shimohara, T.: Characteristics of dust-storm particles and their long-range transport from China to Japan - case studies in April 1993, Atmos. Res., 40, 19-31, doi:10.1016/01698095(95)00023-2, 1996. 